\title{
Not Just a "Conjured Afterthought" $\dagger$ : Using Duress as a Defense for Battered Women Who "Fail to Protect"
}

\author{
Heather R. Skinazi
}

When the state charges a battered woman with failing to protect her child, attorneys seldom raise a duress defense and when they do, courts often express reluctance to accept such a defense in this context. In fact, a battered woman who is charged with killing her abuser and argues self-defense, possesses a better chance of exoneration than a battered woman who is charged with failing to protect her child and argues duress. This Comment contends that the asymmetrical treatment of the "reasonable person" standard in these defenses leads to such strikingly different results. Duress uses a purely objective approach to reasonableness which excludes evidence crucial to demonstrate the reasonableness of a defendant's choices. In comparison, self-defense uses a hybrid objective/subjective approach to reasonableness which ensures that the jury fully understands the totality of the defendant's actions from her own perspective before the jury determines how a reasonable person would have behaved in those same circumstances. The author compares the distinctions separating duress and self-defense, concluding that no logical basis exists for applying different standards of reasonableness to these doctrines and therefore duress should adopt a hybrid approach that resembles self-defense. The author then describes this modification, showing how it could accommodate a defendant who had a reasonable perception of coercion, but one that could only be

Copyright $\odot 1997$ California Law Review, lnc.

$\dagger$ State v. Cross, 391 N.E.2d 319, 323 (Ohio 1979) (referring to duress as "a defense and not a conjured afterthought").

$\ddagger$ B.A. 1994, University of California, Los Angeles; J.D. 1997, Boalt Hall School of Law, University of California, Berkeley. I would like to thank Professor Claire Finkelstein, Tessa Gorman, Machaela Hoctor, Mary Heuett, Nancy Lemon, Kurt Opsahl, Sherri Sokeland and Lisa Arakaki for helpful comments and advice. As always, I am grateful to Sharon and Maurice Skinazi for their unwavering support. 
understood given her experience of prior battering-the "totality of the circumstances."

\section{INTRODUCTION}

A New Mexico trial court convicted Jeanette Williams for failing to protect her four-year-old daughter, Quenetta, from physical abuse by Jeanette's husband.' When the abuse took place, Jeanette was fivemonths pregnant with a second baby and she had been beaten by her husband. He threatened Jeanette's life-and that of Quenetta-if Jeanette interceded. ${ }^{2}$ Although Jeanette did not abuse Quenetta, the state appellate court affirmed her conviction, reasoning that " $[e] v e n$ if [she] could not stop her husband, this did not prevent her from seeking help."3

Battered women in the United States are convicted under a number of different criminal codes for failing to protect their children from abuse and/or neglect. ${ }^{4}$ Child abuse statutes generally appear in two forms: commission statutes, ${ }^{5}$ which convict those who actually inflict

1. See State v. Williarns, 670 P.2d 122, 123 (N.M. Ct. App. 1983).

2. See id. at 124 .

3. Id.

4. This Comment adopts the following distinction between child ahuse and neglect:

Child abuse is the deliberate and willful injury of a child by a caretaker-hitting, beating with a belt, cord or other implement, slamming against a wall, burning with cigarettes, scalding with hot water, locking in a dungeon, hog-tying, torturing, even killing. It involves active, hostile, aggressive physical treatment. Child neglect is more passive negative treatment characterized by a parent or custodian's lack of care and interest, and includes not feeding, not clothing, not looking after, not nurturing. The legal definitions vary in different states; so does the degree of harm done to the child.

Naomi feigelson Chase, A Child Is Being Beaten 1 (1975).

For literature discussing battered women charged with failing to protect their children, see Mary

E. Becker, Double Binds Facing Mothers in Abusive Families: Social Support Systems, Custody Outcomes, and Liability for Acts of Others, 2 U. CHI. L. ScH. RoundTABLE 13 (1995); Bernardine Dohm, Bad Mothers, Good Mothers, and the State: Children on the Margins, 2 U. CHI. L. ScH. Roundtable 1 (1995); V. Pualani Enos, Prosecuting Buttered Mothers: State Laws' Failure to Protect Battered Women and Abused Children, 19 HARv. Women's L.J. 229 (1996); Barbara J. Hart, State Codes on Domestic Violence: Analysis, Commentary and Recommendations, 43 Juv. \& FAM. CT. I No. 4 1992, at 3, 79-80; Kristian Miccio, In the Name of Mothers and Children: Deconstructing the Myth of the Passive Battered Mother and the "Protected Child" in Child Neglect Proceedings, 58 ALB. L. Rev. 1087 (1995); Linda J. Panko, Legal Backlash: The Expanding Liability of Women Who Fail to Protect Their Children from Their Male Partner's Abuse, 6 Hastings Women's L.J. 67 (1995); Dorothy E. Roberts, Motherhood and Crime, 79 lowa L. Rev. 95 (1993); Anne T. Johnson, Comment, Criminal Liability for Parents Who Fail to Protect, 5 LAw \& 1NEQ. J. 359 (1987); Jill A. Phillips, Comment, Re-Victimized Battered Women: Termination of Parental Rights for Failure to Protect Children from Child Abuse, 38 Wayne L. REv. 1549 (1992); Nancy A. Tanck, Note, Commendable or Condemnable? Criminal Liability for Parents Who Fail to Protect Their Children from Abuse, 1987 Wis. L. Rev. 659; Suzanne J. Groisser, Battered Women and Their Battered Children: Criminal and Civil Allegations of the Woman's Failure to Protect 52 (1991) (unpublished paper, on file with author).

5. See, e.g., D.C. CODE ANN. $\$ 22-901$ (1996) (a person is guilty of cruelty to children who "tortures, beats, or otherwise willfully maltreats a child under 18 years of age"). 
abuse, and omission statutes, ${ }^{6}$ such as in Jeanette's case, which criminalize the "passive" conduct of those who expose a child to a risk of maltreatment or fail to protect or care for a child when they have an affirmative duty to do so. Conviction for these crimes usually results in the removal of the children from the mother's care, or termination of her parental rights.

Women who fail to protect their children from violence often possess first-hand knowledge of the abuser. The correlation between wife abuse and child abuse is well established. In homes where mothers are victims of domestic violence, about seventy percent of fathers or fathersubstitutes also beat the children. ${ }^{8}$ The more grievous the abuse of the mother, the greater the likelihood that the child abuse will be severe.? Hence, a battered mother knows better than anyone what the abuser is capable of when he $e^{i 0}$ threatens to harm her or the children if she

6. See, e.g., MONT. CODE ANN. $\$ 45-5-622$ (1991) (a person may commit the offense of endangering the welfare of children "by violating a duty of care, protection, or support"); $c f$. CAL. WELF. \& INST. CODE § 300(i) (Deering Supp. 1997) (a parent or guardian has failed to protect a minor when the parent or guardian "knew or reasonably should have known that the minor was in danger of being subjected to an act or acts of cruelty").

7. See Howard A. Davidson, Child Abuse and Domestic Violence: Legal Connections and Controversies, 29 FAM. L.Q. 357, 358-59 (1995). If a court adjudicates a child as abused or neglected within the statutory definition of the state law, it is authorized by statute to make dispositionul orders generally using a "best interest of the child" standard. See Sally T. Owen \& Herbert H. Hershfang, An Overview of the Legal System: Protecting Children from Abuse and Neglect, in CHLD ABUSE AND NEGLECT 229, 251 (Nancy B. Ebeling \& Deborah A. Hill eds., 1983). "These may include temporary or permanent orders. Children may be removed from the home and transferred to the custody of the state or another agency or individual. The child may be placed in foster care, a group home, residential treatment facility, or hospital." Id. Or children may be allowed to stay at home "with a variety of conditions imposed." Id.

8. See, e.g., Lee H. Bowker et al., On the Relationship Between Wife Beating and Child Abuse, in Feminist Perspectives on Wife Abuse 158, 162-63 (Kersti Yllö \& Michele Bograd eds., 1988) (confirming the $70 \%$ statistic through an empirical study of women with abusive husbands, but positing this figure to be understated because of the women's reluctance to discuss child abuse or because of their lack of knowledge that the abuse took place in their absence); ANGELA BROWNE, WHEN BATTERED WOMEN KILL 70 (1987) (reporting that in her research on women who had killed their male batterers, $71 \%$ of these batterers had also physically and/or sexually abused the children).

Abuse of children often represents an extension of a batterer's coercive tactics from mother to children "as part of an ongoing battering relationship." Evan Stark, Re-presenting Woman Battering: From Battered Woman Syndrome to Coercive Control, 58 ALB. L. Rev. 973, 1017 (1995). Stark labels this "tangential spouse abuse." Id. at 1018.

9. See Bowker et al., supra note 8 .

10. I am unaware of any statistics or case law involving women or men charged with failure to protect who are involved in same-sex relationships. This Comment will thus focus exclusively on heterosexual relationships, but the scope of its proposed modification of duress is not limited to such an application. Further, because among heterosexual couples most acts of violence involve a husband or boyfriend as the abuser, 1 will use the masculine pronoun to refer to batterers.

Although some men are charged with failing to protect their children, this scenario remains rare. For such a case, see In re Brianna Elizabeth M., 452 S.E.2d 454, 458 (W. Va. 1994) (terminating father's parental rights because he refused to acknowledge that his wife inflicted serious injuries upon their dead child and refused to prevent her from having contact with their surviving children). Even when men are charged with failure to protect, the power dynamics in their relationship with the 
disobeys or leaves. Such knowledge explains why a mother may try to placate her batterer at almost any cost to save her children from harm. She may even "allow" the abuse, or stay with the batterer if she thinks it will prevent greater harm to her children." Moreover, battered women's perceptions have a basis in fact. Shielding a child from a violent and angry person is often not only dangerous, but lethal to the intervenor, the child, or others nearby. ${ }^{12}$

Under certain circumstances, one might think that duress would be the appropriate defense to argue when the state charges a battered woman with failing to protect her child. Typically, a duress defense arises when an actor, threatened with imminent death or great bodily harm, commits a criminal act. This act need not be affirmative. Indeed, an omission to perform a legal duty may impose the same amount of liability on the actor. Although some might argue that in the Williams case, Jeanette should have "interfered more" or "tried harder," her choice of how to proceed has to be considered in light of the totality of her coercive circumstances. Jeanette had to weigh the very slight chance of rescue or escape against an increase in the existing greater chance of survival for herself and her daughter, Quenetta, if she obeyed her husband. The choice was not between a certainty and a chance, but rather, between two chances-"something horrible and something really horrible."13 Such a choice represents the paradigmatic duress dilemma.

Jeanette's attorney, however, did not present a duress theory. She is not alone in this regard. Although attorneys are increasingly raising duress defenses for battered women indicted for other crimes, ${ }^{14}$ claiming they committed the crime because a spouse or boyfriend beat them or threatened greater harm to them or their family members if they refused

women who abuse the children differ vastly from when women are charged with this crime. See Roberts, supra note 4 , at $127-28 \&$ n.164. In such situations, the man is rarely battered himself.

11. See infra text accompanying notes $48-59$.

12. See infra text accompanying notes 48-53.

13. Rebecca Sisco, Villain or Victim? Janice Loch Case Raises Disturbing Moral Questions, Minn. WoMEN's PrEss, Mar. 24-April 6, 1993, at 1, 10.

14. See United States v. Willis, 38 F.3d 170, 173 (5th Cir. I994), cert. denied, 1 I5 S. Ct. 2585 (1995) (carrying firearm during drug trafficking crime); United States v. Homick, 964 F.2d 899, 90I (9th Cir. 1992) (wire fraud); Unitcd States v. Sebresos, 972 F.2d 1347, 1992 WL 170987, at *1-3 (9th Cir. 1992) (unpublished table disposition) (embezzlement); United States v. Simpson, 979 F.2d 1282, 1284 (8th Cir. 1992) (aiding and abetting armed bank robbery and use of firearm in commission of violent felony); United States v. Sixty Acres, 930 F.2d 857, 858 (11th Cir. 1991) (civil forfeiture proceeding of wife's property used by husband to grow marijuana); United States v. Marenghi, $893 \mathrm{~F}$. Supp. 85, 91-97 (D. Me. 1995) (conspiracy to possess and distribute controlled substance); People v. Yaklich, 833 P.2d 758, 759 (Colo. Ct. App. 1991) (conspiracy to commit first-degree murder); State v. Daoud, 679 A.2d 577 (N.H. 1996) (driving vhile intoxicated); State v. Lundgren, No. 90-L-15-125, 1994 WL 171657, at *1 (Ohio Ct. App. April 22, 1994) (complicity in commission of aggravated murder, conspiracy to commit aggravated murder and kidnapping); State v. Loven, No. 34907-4-1, 1996 WL 280764, at *1 (Wash. Ct. App. May 28, 1996) (unpublished disposition) (first-degrec rape of a child); State v. Lambert, 312 S.E.2d 31, 32 (W. Va. 1984) (welfare fraud). 
to comply, attorneys are reluctant to raise a duress defense to excuse battered mothers charged with failing to protect their children.

Admittedly, the objective standard of reasonableness dictated by traditional duress doctrine, which requires that the defendant was reasonable in believing herself to be subject to imminent death or great bodily harm, would exonerate only a small class of these defendants. In comparison, a battered woman who kills her abuser and argues selfdefense possesses a better chance of exoneration than a battered woman who is charged with failing to protect her child and argues duress. The crux of my argument is that the criminal law's asymmetrical treatment of the reasonable person standard in these defenses causes this disparity. While self-defense adopts a hybrid objective/subjective approach to determine how a reasonable person would behave, duress uses a purely objective test which often excludes evidence crucial to demonstrate the defendant's credibility. I claim that no logical basis exists for this disparity and that the duress defense should be changed to adopt the hybrid test. Modifying duress to incorporate the approach to reasonableness used by self-defense is consistent with the duress defense's underlying excuse rationale, which holds that punishing reasonable and coerced behavior is unjust. Such a modification would accommodate a defendant who had a reasonable perception of coercion that could only be understood given her experience of prior battering.

In Part I, I present a background of duress and discuss the traditional objective approach to reasonableness the defense adopts. I conclude that, even if attorneys raise a defense of duress for battered women charged with failure to protect, courts are unlikely to exculpate battered women under the objective approach. Rather, courts are apt to distrust the defendant's credibility, given both the narrow scope of the defense as well as the probability that attorueys will present their clients as impaired victims of "learned helplessness." In Part $I$, I turn to selfdefense and examine its hybrid approach to reasonableness.

Next, I compare the approaches to reasonableness used by duress and self-defense in Part III, finding that no sufficient reason exists to sustain the aforementioned asymmetry. In Part IV, I consider the application of a modified duress defense to battered women charged with failure to protect. I attempt to construct a theory of culpability that better explains the moral accountability of battered women charged with this crime. To that end, I analyze the ways that duress can account for the complex circumstances involved in such situations. I argue that a hybrid approach, as used in self-defense, best accomplishes the aim of determining how a reasonable person would have behaved. This new standard also modifies the duress defense's traditional imminence requirement by adopting a totality-of-the-circumstances approach to 
highlight the structural, personal, and contextual coercion under which a battered woman makes reasonable survival choices. By inquiring into the violent attempts at power and control batterers make over their intimate partners and how abused mothers struggle to operate within the limits of that power and control, this approach views the abused mother neither simply as a victim nor as a survivor, but as a proactive person who often must make decisions under the worst of conditions.

In Part V, I explore how the modified duress standard would apply to failure-to-protect cases that duress is not traditionally thought to excuse. Finally, I conclude that the criminal justice system can serve the best interests of both abused mothers and their abused children by adopting the modification of duress that this Comment proposes.

While I focus on how failure-to-protect laws affect battered women, these laws affect children because of the inextricable link between mother and child. Consideration of the child's welfare underlies my entire analysis, as often "the best way to protect children is to protect their mothers."15 I will not argue that battered women who are unfit mothers should retain custody of their children because they are battered women, just as I would not contend that women should retain custody of their children because they are women. ${ }^{16}$ Some mothers do not care about their children and even maliciously participate in abusing them. ${ }^{17}$ Unquestionably, children need protection from violent parents. ${ }^{18}$

15. Leticia Sierra, National Clearinghouse for the Defense of Battered Women, Representing Battered Women Charged with Crimes for Falling to Protect Their Children from ABusive Partners 1 (1996).

16. I do not subscribe to the essentialist notion that biology determines destiny, nor that women's nature somehow makes them better parents. For such a view, see CArol MCMiLLAN, WoMEN, REASON, AND NATURE (1982) (reifying the dichotomy between reason and emotion in an attempt to define women's "true maternal nature").

17. See, e.g., Cardona v. State, 641 So.2d 361 (Fla. 1994), cert. denied, 115 S. Ct. 1122 (1995) (affirming mother's conviction and death sentence for aggravated child abuse and first-degree murder of her three-year-old son); David Van Biema, Abandoned to Her Fate, TME, Dec. 11. 1995, at 33 (discussing five-year-old girl bludgeoned to death by her mother).

However, even the most horrific instances of child abuse are simplified by the mass media. On the particular difficulties women who abuse their children pose for feminists and especially feminist attorneys who represent them, see Marie Ashe \& Naomi R. Cahn, Child Abuse: A Problem for Feminist Theory, 2 TEx. J. WOMEN \& L. 75, 76 (1993) (arguing that aecounts of child abuse delivered through the popular media have tended to reduce child abuse to a story of "bad mothers"). The authors provide personal accounts of their perceptions of bad mothers based on firsthand experiences representing such clients in judicial proceedings in which they have been charged with abuse or neglect. See id.; see also Marie Ashe, Postmodernism, Legal Ethics, and Representation of "Bad Mothers," in Mothers iN LAW 142 (Martha Albertson Fineman \& Isabel Karpin eds., 1995) (same).

18. The sheer number of child abuse and neglect cases represents one of the most disturbing problems of recent times. In California's Alameda County alone, 300 children are abandoned or neglected each month, and the number of children in permanent foster care in the county has reached about 3,000. See Henry K. Lee, 4 Children Left Alone in Oakland: No Food or Heat for 2 Days, S.F. Chron., March 1, 1996, at A19, A24. 
But convicting a non-abusing battered mother for failure to protect will not benefit children, rather it only serves to revictimize both mother and child who have suffered enough abuse. No child should be wrenched from a loving and good parent simply because that parent has been battered.

\section{Duress: The Objective Approach to Reasonableness}

\section{A. Background and Elements of Duress}

Although the duress defense dates back to English common law, ${ }^{19}$ society continues to experience what one legal scholar has aptly termed a "love-hate relationship"20 with it. Indeed, proposals ranging from abolishing the defense ${ }^{21}$ to expanding $\mathrm{it}^{22}$ have garnered support at one time or another. Joshua Dressler asserts that society holds such conflicting reactions to the defense because it coincides so precisely with our unsettled emotions toward coerced actors. ${ }^{23}$ That is, we are often torn between sympathy for the coerced actor and abhorrence at the act she committed. Duress forces society to confront the question of what conduct it legitimately expects from threatened citizens. While

19. At common law, duress represented one of three forms of recognized coercion. See 4 William Blackstone, Commentaries *30; see also infra note 177.

20. Joshua Dressler, Exegesis of the Law of Duress: Justifying the Excuse and Searching for Its Proper Limits, 62 S. CAL. L. REv. 1331, 1331 (1989).

21. See Douglas Aikenhead Stroud, Mens Rea 26 (1914); see also Regina v. Tyler, 8 Eng. Rep. 616, 620-21 (Maidstone Assizes 1838) (" $[\mathrm{N}] \mathrm{o}$ man, from a fear of consequences to himself, has a right to make himself a party to committing mischief on mankind.... It cannot be too often repeated, that the apprehension of personal danger does not furnish any excuse for assisting in doing any act which is illegal."); SiR James FitzJames Stephen, 2 A History of the Crimin al LAw OF ENGLAND 108 (1883) ("[C]ompulsion by threats ought in no case whatever to be admitted as an excuse for crime.").

22. For a discussion of suggestions to broaden duress to permit an excuse for criminal wrongdoing that results from social and economic deprivation, otherwise known as the "rotten social background" or "brainwashing" defenses, see Peter Allridge, Brainwashing as a Criminal Law Defence, 1984 CRIM. L. REv. 726; Richard Delgado, Ascription of Criminal States of Mind: Toward a Defense Theory for the Coercively Persuaded ("Brainwashed") Defendant, 63 MiNN. L. REv. I (1978); Richard Delgado, "Rotten Social Background": Should the Criminal Law Recognize a Defense of Severe Environmental Deprivation?, 3 LAW \& INEQ. J. 9 (1985); Donald T. Lunde \& Thomas E. Wilson, Brainwashing as a Defense to Criminal Liability: Patty Hearst Revisited, 13 CRIM. L. BuLl. 341, 358-60 (1977).

23. See Dressler, supra note 20 , at 1332 . This leads Dressler to label duress as a "normative defense;" the "actor should be excused only if he attained or reflected society's legitimate expectations of moral strength." Id. at 1334. Dressler contends that duress is an "atypical excuse," id. at 1356 , because in most excusing situations, such as insanity, infancy or involuntary intoxication, the criminal law considers a defendant blameless, because she substantially lacked the capacity for free choice. See id. at 1357. In contrast, with duress the coerced actor possesses the capacity for free choice because she possesses practical reasoning skills and is a morally responsible agent. Moreover, not only does she possess the capacity to understand the attendant factual and legal circumstances, she realizes just what it is she is doing. See id. at 1360; see also infra text accompanying note 35. 
commentators and philosophers continue to debate whether duress should be categorized as an excuse, ${ }^{24}$ a justification, ${ }^{25}$ or perhaps somewhere in between ${ }^{26}$ the consensus seems to favor excuse.

Generally, both justification and excuse defenses are applicable to all criminal offenses. These defenses acknowledge that the defendant has committed the crime charged, but assert that she should not be criminally liable for her actions. Justifications aver that the defendant's act was right, or at least legally permissible, and thus she is not morally blameworthy. Arriving at this determination involves weighing the harm a defendant caused by deviating from the letter of the law against the social benefit realized through her conduct. If, on balance, the benefit outweighs the harm to society, the law deems the defendant to have chosen the proper course of behavior and exonerates her. ${ }^{27}$ American criminal codes usually treat crimes of self-defense, defense of others, defense of property, and necessity as justifications. ${ }^{28}$

In contrast to justifications, which negate the social harm of an actor's act, excuses negate the moral blameworthiness of the actor for causing the harm: "[T]he nature of an excuse is to personalize the plea so that, while justification looks to the rightness of the act, excuse speaks to the compassion of the court for the actor."29 Rather than focus on the act itself, excuses center on the accused and the unique facts of her case, such as the pressures she faced at the time of her criminal act. An excuse concedes the criminal act was wrong, but nonetheless claims that, because the actor "lacked a fair opportunity to avoid acting unlawfully," ${ }^{30}$ she should not be blamed for it. Consequently, while a

24. See George P. Fletcher, Rethinking Criminal Law $\$ 10.4 .2$ (1978); 2 Paul H Robinson, Criminal Law Defenses $\$ 177$ (e) (1984); Rollin M. Perisins \& Ronald N. Boyce, Criminal LAw 1059 (3d ed. 1982); Dressler, supra note 20, at 1356-67; Claire O. Finkelstein, Duress: A Philosophical Account of the Defense in Law, 37 ARIz. L. REv. 251, 261-63 (1995); Sanford H. Kadish, Excusing Crime. 75 CALIF. L. Rev. 257, 261-62 (1987).

25. See Wayne R. Lafave \& Austin W. Scott, Jr., Criminal Law § 5.3, at 433 (2d ed. 1986) (citing the rationale of duress as one of social policy: "[I]t is better that the defendant, faced with a choice of evils, choose to commit the lesser evil ... to avoid the greater evil threatened by the other person."); Glanville Williams, CRIMinal, LAW § 246 (2d ed. 1961).

26. See Kent Greenawalt, The Perplexing Borders of Justification and Excuse, 84 CoLum. L. REv. 1897, 1912 (1984) (arguing that duress covers behavior that is justified as well as excused).

27. For less prevalent theories of justifications, see JoshUA DRESSLER, UNDERSTANDING Criminal. Law § 17.04[C]-[D] (2d ed. 1995).

28. See 1 RoBINSON, supra note $24, \S 24(a)$. For a "counterintuitive option" to this classification of self-defense, see Claire O. Finkelstein, Self-Defense as a Rational Excuse, 57 U. PrTT. L. REv. 621,624 (1996) (arguing that self-defense cases should be thought of as excused rather than justified killing).

29. Perka v. The Queen [1984] D.L.R. (4th) 1, 30 (Can.) (Wilson, J).

30. Dressler, supra note 20, at 1365. Dressler later clarifies this statement, explaining that a coerced person, by definition, never truly possesses a "fair opportunity" because of the wrongfulness of the coercer's threats. See id. at 1366. Blackstone defines such a crime of compulsion as a "constraint[] upon the will, whereby a man is urged to do that which his judgment disapproves, and 
justification requires that the defendant's act be socially desirable, because it must have avoided the greater evil of the threatened harm, an excuse might hold even where the cost of the defendaut's act greatly exceeds its benefits. In addition to duress, the criminal law generally classifies insanity, infancy, and involuntary intoxication as excuses. ${ }^{31}$

Because duress is an excuse, it does not mandate society's admission that the defendaut's criminal offense was a good act per se, but rather it allows society to exculpate the particular offender because she is not blameworthy. The basic requirements for use of the duress defense are: (1) threat of death or great bodily harm to the defendant or another that causes the defendant reasonably to believe her life or that of another is endangered, (2) commission of the crime while the defendant's fear of death is immediate and imminent, and (3) existence of a reasonable relationship between the circumstances surrounding the threat and the crime committed. Some jurisdictions also require that the defendant not recklessly or negligently place herself in a situation where duress could arise. ${ }^{32}$ Thus, duress will usually only excuse a defendant's criminal act if the coercer's threat was imminent and the defendant did not possess a reasonable opportunity to escape..$^{33}$

As a species of excuse, the elements of coercion and reasonableness lay at the core of this defense. However, the criminal law and most commentators traditionally associate reasonableness with justifications rather than excuses - assuming that acts deserving of excuse are those that involve uncontrollable, involuntary, irrational, and therefore unreasonable behavior. It is thought that actors who commit crimes under such conditions lack moral responsibility for their actions precisely because they are involuntary. ${ }^{34}$ While excuses such as insanity and infancy, as well as some claims of intoxication, often involve involuntary

which, it is to be presumed, his will (if left to itself) would reject." BLACKSTONE, supra note 19, at *27.

31. See 1 Robinson, supra note $24, \S 25(c)$.

32. See infra note 157 and accompanying text.

33. While no unanimity exists among the courts regarding the precise elements of duress, as the Supreme Court observed, "Under any definition of [the defenses of duress and necessity] one principle remains coustant: if there was a reasonable, legal alternative to violating the law, 'a chance both to refuse to do the criminal act and also to avoid the threatened harm,' the defenses will fail." United States v. Bailey, 444 U.S. 394, 410 (1980) (emphasis added) (citation omitted).

Some commentators argue that the nature of the threat distinguishes duress from necessity. At common law and in some jurisdictions today, duress requires pressure from other people, whereas necessity requires pressure from physical, natural causes. See LAFAVE \& ScotT, supra note $25, \S$ 5.3. The justification/excuse distinction has now largely replaced the source of the threat distinction. See 1 RoBinson, supra note $24, \$ 27($ b) $; 2$ id., supra note $24, \S 177$ (e)(1).

34. For example, George Fletcher states that "excusing conditions ... all speak in the idiom of involuntariness." George P. Fletcher, The Individualization of Excusing Conditions, 47 S. CAL. L REv. 1269, 1271 (1974). But see Finkelstein, supra note 24, at 270 ("It is the contention of this Article that duress does not involve involuntariness of any sort."). 
behavior, an act committed under duress is the product of a rational mind: $B$, although acting under fear, takes rational, willed steps to avoid the danger A threatens. ${ }^{35}$ Although $\mathrm{B}$ is fearful and does not desire to commit the criminal act $\mathrm{A}$ commands, $\mathrm{B}$ intends to commit the criminal act. B performs the act voluntarily and perhaps sensibly, if it represents what she considers to be the best option under the circumstances. By this definition, B is morally responsible for her voluntary act, yet she is not blameworthy precisely because her act was a reasonable one in light of her coercive circumstances.

\section{B. An Unreasonable Standard of Reasonableness for Battered Women}

Courts currently evaluate whether a defendant has satisfied the duress defense's requirements using an objective analysis, which posits a standard (nonindividualized) test to adjudicate the claims of an individual defendant. ${ }^{36}$ One asks whether the reasonable person, or some analogue, would yield to the pressure. The objective standard of the reasonable person serves two functions. First, it carries out an evidentiary function by confirming that the actor was in a state of coercion. Second, it fulfills a normative function by ensuring that the threat was sufficient to invoke the community's standards for blamelessness. In this way, the standard bars the defense to an actor who was merely timid or easily coerced..$^{37}$

Applying a purely objective test is quite difficult. Often, the exceptional nature of the circumstances that impelled the defendant to commit the crime make it nearly impossible for a jury to compare her with a hypothetical reasonable person. A jury cannot say for certain how this hypothetical person would have acted in the same situation. To do so, the juror must first imagine a reasonable person, decide what a reasonable belief for this reasonable person would be, and then compare this belief with the belief of the defendant. Jody Armour refers to this test as "the problem of the Procrustean bed." ${ }^{38} \mathrm{He}$ explains,

In Greek mythology, Procrustes was a highwayman who waylaid unsuspecting travelers and dragged them to his lair, where he bound them to his bed. Although the abducted travelers came in many different sizes, Procrustes's bed came in only one. If a hapless traveler proved too short for his host's bed, Procrustes

35. See Finkelstein, supra note 24 , at 252 (proposing interpretation of duress as an excuse not based on lack of responsibility). In a more recent article on self-defense, Finkelstein labels this species of excuse as "rational excuse." Finkelstein, supra note 28, at 623.

36. See, e.g., United States v. Villegas, 899 F.2d 1324, 1344 (2nd Cir. 1990) (requiring "wellfounded fear" and "no reasonable opportunity to escape" for duress defense).

37. See 2 Robinson, supra note $24, \S 177(d)$.

38. Jody Armour, Just Deserts [sic]: Narrative, Perspective, Choice, and Blame, 57 U. PITT. L Rev. 525, 528 n.8 (1996). 
racked and stretched him into conformity; too long, Procrustes lopped of [sic] the offending extremities. In the end, the diversity of dimensions that the different travelers embodied was reduced to blank uniformity. ${ }^{39}$

\section{Objective Approach Assumes No Threat of Imminent Death or Great Bodily Harm}

Battered mothers' failure-to-protect crimes evade such neat, objective categorization. Consideration of the defendant's heightened ability to predict her partner's behavior toward herself and her children-a skill she has developed through a history of abuse with her partner-is crucial in determining whether the defendant's responses to his threats were, in fact, reasonable. Additionally, because in most of these cases, the paradigm "gun to the head,"40 or some other obviously extreme example of duress, is not present, or at least not apparent, a jury using an objective standard of reasonableness is not likely to believe that the defendant acted reasonably under a sufficiently imminent threat. Generally then, adherence to the narrow test precludes the possibility of a successful defense. One public defender succinctly explains, "most jurors believe that a person can refrain from committing a criminal act unless they are insane." ${ }^{.41}$

For example, judges and jurors usually disregard a mother's fears of her batterer by substituting their own judgment (via the objective reasonable person) that she could have safely taken action to prevent harm to her children. As one person put it, "A mother protects her child against all odds-and I don't care if that mother is battered to a pulp." ${ }^{\prime 2}$ Consequently, courts often express reluctance to accept a duress defense in this context, assuming that protecting a child would not entail risking additional injury. Courts find that the defendant is not really faced with a duress situation, because no threat of imminent death or great bodily harm exists.

\section{Objective Approach Assumes Reasonable Opportunity to Escape}

The objective test also fails to recognize "the effects of subtle, ongoing forms of physical and psychological abuse." ${ }^{943}$ While sometimes

39. Id.

40. George P. Fletcher, Basic Concepts of Legal Thought 105 (1996). Fletcher's full sentence reads, "The proverbial mode of duress is a gun pointed at the head as the ultimate persuader to do (or not do) something ... and right now!" Id.

41. Telephone Interview with Kort Gatterdam, Assistant Ohio State Public Defender, one of the attomeys who represented Edna Mae Engle in State v. Engle, 660 N.E.2d 450 (Ohio 1996) (March 1, 1996). See infra note 72.

42. Mary Jo Hazard, Battered Women, L.A. Times, Mar. 30, 1989, § 2 (Metro), at 6 (letter to the editor regarding Hedda Nussbaum, a battered woman whose daughter died from child abuse).

43. United States v. Gaviria, 804 F. Supp. 476, 478 (E.D.N.Y. 1992). 
only several hours elapse between the actual threat and the charged offense, days, ${ }^{44}$ weeks, ${ }^{45}$ months, ${ }^{46}$ or maybe even years ${ }^{47}$ may pass. Triers of fact usually question the battered woman's failure to leave, and specifically in failure-to-protect cases, her failure to leave with her children. Such questions reveal society's lack of knowledge about domestic violence. Although well-intentioned, these inquiries ignore the complex dynamic that may compel a battered woman to remain with her abuser. Most people do not realize that battering often becomes most acute when a woman leaves. Abusive men who are threatened with loss of their mates tend to become severely depressed, angry, or even homicidal..$^{48} \mathrm{By}$ some estimates, at least fifty percent of women who leave their abusers are followed and harassed or further attacked by them. ${ }^{49}$ Violent men may search desperately for their partners once they leave:

Often, they spend their days and nights calling her family and mutual acquaintances; phoning her place of employment or showing up there; driving around the streets looking for her; haunting school grounds, playgrounds, and grocery stores. If they believe the woman has left town, they frequently attempt to follow her, traveling to all locations they think she might be

44. For a rare example of a successful defense to a failure-to-protect charge, see In re Betty J.W., 371 S.E.2d 326 (W. Va. 1988) (granting defendant improvement period without custody of her children before termination of her parental rights where defendant waited a day to report child abuse until abusive spouse left home, and she had attempted to stop the abuse). The success of the case seemed to tum on the short time-lag. But see Commonwealth v. Lazarovich, 574 N.E.2d 340, 342-43 (Mass. 1991) (affirming conviction of defendant for mayhem, assault and battery, even though she waited only one day to take abused child to hospital and even though spouse who had abused child and the defendant would not allow defendant to leave and she was afraid of leaving her other two children alone with him).

45. See infra text accompanying notes 60-67.

46. See, e.g., Commonwealth v. Beeler, No. 90-10680, slip op. (Pa. C.P. July 29, 1991), vacated, 627 A.2d 199 (1993) (holding that defendant charged with assisting boyfriend in sexually assaulting her daughter failed to show duress because by purely objective standard, defendant possessed a reasonable opportunity to escape). In ruling against Beeler, the court stated:

Defendant only vaguely described the harm she believed would come about had she acted to prevent the sexual abuse of Child, or refrained from participating in the sex acts. She stated, for instance, that her paramour at one point raped her and beat her when she resisted his desires. ... Defendant, over the course of five months, failed to take any legal action to prevent her paramour from committing sex acts upon Child, and actively assisted her paramour when he committed sex acts upon Child.... Quite simply we have not been able to find credible the Defendant's protestations of fear.

Id. at 6-7 (emphasis added).

47. See, e.g., In re Dalton, 424 N.E.2d 1226, 1230 (11l. App. Ct. 1981) (affirming termination of mother's parental rights for failing to protect children from abusive husband where ongoing abuse occurred for years despite mother's continual efforts to escape with children only to be stalked and kidnapped by husband). The trial court stated that when "considering the lengthy periods of time ... it [the "defense of fear"] is not reasonable or credible when one considers [the] time element and the different geographical locations over which [the abuse] took place.... [O]ne would have to be devoid of almost all reason to have that be credible ...." Id. at 1232.

48. See Martha R. Mahoney, Legal Images of Battered Women: Redefining the Issue of Separation, 90 Mrch. L. REv. 1, 6 (1991) (proposing theory of "separation assault").

49. See Browne, supra note 8, at 110 (citing DonNa M. MoORE, Battered Women (1979)). 
found. She is theirs. She cannot leave and refuse to talk to them. ${ }^{50}$

Many battered women report that leaving their mates and living in constant fear of reprisal or death seems less tolerable than staying, despite their fears of further harm. ${ }^{51}$ Sarah Buel, a domestic violence survivor, states that "one of the most common reasons that many of us stay [is that] [w]e can better protect our children if we are there and can see the abuser than if we're on the run, and he has the opportunity and advantage of being able to track us down." 52 Still, on average, a battered woman attempts to leave her partner five times before successfully breaking free. ${ }^{53}$

In addition to fearing future violent episodes and believing that the batterer might kill them and their children if they attempt to leave, battered women fear that either the abuser or the state will take their children away. ${ }^{54}$ Batterers may threaten or try to kidnap, harm, or seek custody of the children if their partner tries to leave ${ }^{55}$ or call the police

50. BROWNE, supra note 8, at 115 .

51. See id.

52. Sarah Buel, The Dynamics of Family Violence, in Courts AND Communities: Confronting VIolence in the Family 7, 11 (National Council of Juv. \& Fam. Ct. Judges ed., 1993).

53. See Lenore E Walker, The Battered Woman 199 (1979).

54. See Marsha B. Liss \& Geraldine Butts Stahly, Domestic Violence and Child Custody, in Battering AND FAMILY Therapy 175, 179-82 (Marsali Hansen \& Michèle Harway eds., 1993).

Further reasons why a battered woman might remain with the abuser include other family and/or legal pressures. She may stay out of a sense of shame and responsibility. Typically, women are socialized to believe that they are failures as women if their relationships fail, because relationships should be perfect. See, e.g., BELL HOOKS, TALKING BACK 90 (1989). A woman may stay because she is economically dependent on the abuser. Further, many battered women's shelters do not accept women with children and those that do are often full. See BrownE, supra note 8, at 111. Money, however, does not protect women from battering. Middle and upper-class women get battered as much as lower-class women. See WALKER, supra note 53, at 21-22. A woman may also stay because of issues relating to undocumented alien status. See Deeana L. Jang, Caught in a Web: Immigrant Women and Domestic Violence, 1994 NAT'L ClearinghouSe 397, 400. And she may stay because she has been called a provoker and masochist by misinformed professionals whose attitudes serve to entrench her further in a dangerous situation.

55. See, e.g., In re Dalton, 424 N.E.2d 1226, 1229-30 (11l. App. Ct. 1981) (detailing that every time battered wife took children and left husband, he hunted the family down to drag them back and then threatened to kill the children if his wife ever left him again). One neighbor witnessed the husband "hold one of the children outside of the third floor window and threaten to drop him in order to coerce [his wife] into remaining with him... [O]n one occasion [the husband] tried to run the children over with a car, and, on another, [he] threatened to kill them." Id. at 1230.

A woman could also lose custody of her children if she flees without them. Such a situation occurred after a woman obtained a restraining order against her husband; he suddenly appeared in her bedroom one night wielding a gun and she fled into the night alone. See Christine A. Littleton, Women's Experience and the Problem of Transition: Perspectives on Male Battering of Women, 23 U. CHI. Legal. F. 23, 54 (1989). The father subsequently claimed that his wife had deserted their children. See id. 
for help..$^{56}$ And even if a battered woman successfully escapes with her children, the batterer may accuse her of "kidnapping" them. The state may seek to remove the children from their mother, impose legal restrictions on the care and custody of her children, or terminate her parental rights. ${ }^{57}$ The state might even award custody of the children to the batterer. In fact, it is not uncommon for batterers to win custody of their children, because in litigation concerning custody, a man's violence against his wife is not the issue before the court, especially if no evidence exists that he physically abused the child. ${ }^{58}$

From the battered woman's perspective then, it becomes understandable why it may have been patently unreasonable for her to interfere with the batterer's abuse of the child. Based on her experience, she reasonably feared that interference would either increase the abuse to the child or precipitate deadly violence against herself and the child. ${ }^{59}$ Given the batterer's history of violence toward her, the woman knows that he is both likely and capable of carrying through on his threats. As suggested earlier though, courts often exclude the batterer's violent history under an exclusively objective approach to reasonableness. Courts consider this information as outside of the time frame relevant to assess a defendant's duress claim. Thus, battered women attempting to satisfy the requirements of the duress defense must convince a jury that an "objectively" reasonable person with no history or knowledge of the batterer's violence would have been unable to resist the batterer's coercion.

56. See, e.g., Commonwealth v. Lazarovich, 574 N.E.2d 340 (Mass. 1991). In this failure-toprotect case, after throwing the defendant, Janice Lazarovich, on the floor, her husband, Roger, who had beaten her since the beginning of their marriage, went to their children's room. See id. at 342 . Janice then called the police. See id. After the police left, Roger picked up their youngest son in one hand and a knife in the other. See id. Roger threatened Janice that if she ever phoned the police again, "he would cut [the boy's] f_— head off." Id. Roger then released the boy and threw Janice against a wall, knocking her unconscious. See id.

57. See Davidson, supra note 7, at 366-67.

58. See Browne, supra note 8, at 111; Phyllis Chessler, Mothers on Timal: The Battle For Children ANd Custody 148-70 (1986); see also Carol A. Witt, The Impact of Domestic Violence on Child Custody.MAss. LAw. WKLY., Aug. 28, 1995, at All (citing the 1989 Gender Bius Study of Courts in the Commonwealth of Massachusetts conducted by the Supreme Judicial Court).

59. After all, domestic violence is the leading cause of women's deaths in the United States. See Susan A. MacManus \& Nikki R. Van Hightower, Limits of State Constitutional Guarantees: Lessons from Efforts to Implement Domestic Violence Policies, 49 PuB. ADMIN. REv. 269, 269 (1989). Former Surgeon General C. Everett Koop identified violence against women by their partners as the leading hcalth problem for women living in the United States. See Barbara J. Hart, The Legal Road to Freedom, in BatTering and - FAMILY Therapy, supra note 54, at 13, 18 ("Domestic violence causes more injuries to women than automobile accidents, muggings, and rapes combined.") (citation omitted). Thirty percent of all female homicide victims die as a result of domestic violence. See Francis T. Murphy, Struggling Against Domestic Violence, N.Y. LJ., May 2, 1994, at S1. Women are most likely to be murdered when they attempt to report abuse or to leave abusive relationships. See BrowNE, supra note 8, at 113-16; Mahoney, supra note 48, at 65-77. 
In United States $v$. Webb, ${ }^{60}$ one of the rare cases in which a battered woman charged with failure to protect pled duress, the defense failed. The appellate court decision did not report the jury's reasoning for finding the defendant, June Webb, guilty. However, an examination of the facts of the case reveals that the jury's verdict turned on the court's use of an objective standard of reasonableness. June's husband, Keith, beat her and their six-year-old son, Steve, for several years. ${ }^{61}$ The child finally died as a result of a failure to get medical care for his injuries, and Keith buried him in the desert. ${ }^{62}$ About a month later, June persuaded Keith to drive her to the authorities by claiming that another man had raped her ${ }^{63}$ When she was taken into a room out of Keith's earshot, she reported Steven's death to the authorities and accused Keith of causing the death. ${ }^{64}$ June stated that she was unable to report the death earlier because Keith had threatened to kill her, her other children, and her family in Delaware if she reported him..$^{65}$

The trial court instructed the jury that if it found June had possessed "no reasonable opportunity to escape the compulsion," find her innocent. But by using an objective standard of duress and not allowing expert testimony about a battered woman's experiences, the trial court denied June the opportunity to bolster her credibility before the jury. The jury heard no evidence explaining why a battered woman may not be able to leave her batterer and go to the authorities for protection. In all likelihood, then, the jurors could not understand why June was able to go to the authorities one month after Steve's death, but not when Keith was abusing the child. The appellate court affirmed June's conviction. ${ }^{67}$

\section{Objective Approach Assumes Being Battered and Being Reasonable} Are Mutually Exclusive

As in Webb, courts that adopt an objective standard of reasonableness for duress often exclude battered-woman-syndrome evidence. ${ }^{68}$

60. 747 F.2d 278 (5th Cir. 1984). This case appears to be the first published decision in which a battered defendant charged with failure to protect pled duress.

61. See id. at $280-81$.

62. See id. at 281.

63. See id.

64. See id.

65. See id.

66. Id. at 285.

67. See id. at 286.

68. Some courts that use the objective standard of reasonableness to judge claims of duress have allowed battered-women-syndrome evidence to be considered, but only as a mitigating factor in sentencing. See, e.g., United States v. Johnson, 956 F.2d 894, 898, 902-03 (9th Cir. 1992). See generally Laurie Kratky Dore, Downward Adjustment and the Slippery Slope: The Use of Duress in Defense of Battered Offenders, 56 Oн10 ST. L.J. 665, 738 (1995). 
These courts characterize such evidence as "inherently subjective," because it is offered "to explain why this particular defendant succumbed when a reasonable person without a background of being battered might not have." Specifically, courts contend that battered-womansyndrome evidence "seeks to establish that, because of her psychological condition, the defendant is unusually susceptible to the coercion."70 Thus, part of the courts' reluctance to accept any testimony on a battered woman's experiences stems from the way in which battered woman syndrome has been explained-namely, as the "irrational product of a 'mental health disorder." "' Conceived of in this way, being battered and being reasonable are mutually exclusive. ${ }^{72}$

While crafting a duress defense for June Webb, June's attorney sought to establish that her actions were involuntary. ${ }^{73}$ Framing June's actions in this way reaffirms the manner in which some courts and commentators interpret duress. ${ }^{74}$ It also accords with the widespread conception of battered woman syndrome first suggested by Lenore Walker. ${ }^{75}$ Most prominent in Walker's cycle theory of violence is the notion of "learned helplessness." "76 This notion suggests that a battered

69. United States v. Willis, 38 F.3d 170, 175 (5th Cir. 1994), cert. denied, 115 S. Ct. 2585 (1995) (emphasis added); see also State v. Riker, 869 P.2d 43, 50-51 (Wash. 1994) ("Exclusion of [batteredwoman-syndrome expert] testimony in this case ... accords with the law's traditional skepticism regarding the defense of duress.").

70. Willis, $38 \mathrm{~F} .3 \mathrm{~d}$ at 175 (emphasis added).

71. Anne M. Coughlin, Excusing Women, 82 CaLIF. L. Rev. 1, 5 (1994) (quoting Lenore E. Walker, Battered Woman Syndrome and Self-Defense, 6 Notre Dame J.L. Ethics \& Pub. Pol'y 321,331 (1992)).

72. See, e.g., State v. Edwards, 420 So.2d 663, 677-78 (La. 1982) (viewing testimony on battered woman syndrome as an attempt to introduce evidence of insanity or mental defect); State v. Felton, 329 N.W.2d 161, 175 (Wis. 1983) (ordering new trial for battered woman convicted of murdering her husband so that she could assert the defense of not guilty by reason of mental discase or defect).

In State v. Engle, 660 N.E.2d 450 (Ohio 1996), the defendant, Enda Mae Engle, was indicted for, among other offenses, aggravated murder, abuse of a corpse, and child endangerment. See $i d$. at 451. At trial, Enda sought to establish that her husband, who was convicted of the son's death, beat and threatened her to keep her quiet. See Appellant's Brief at 6-8, Engle (No. 38-CA-OCT-92). Before any evidence was presented, the state filed a motion in limine to disallow Edna's expert testimony on battered woman syndrome as it related to duress, anticipating that such evidence would characterize the defendant's mental state as a type of stress disorder. See id. at A-26. Accordingly, the state argued that this evidence would not be relevant because "[d]iminished capacity is not reeognized as a defense in Ohio." Id. The trial court granted the motion, stating that psychiatric testimony would only be admissible to establish an insanity defense. See id. at A-29. On the fallacy of labeling a duress defense for battered women as one of diminished capacity, see supra notes 175-181 and accompanying text.

73. See United States v. Webb, 747 F.2d 278, 284 (5th Cir. 1984).

74. See supra note 34 and accompanying text.

75. Battered woman syndrome describes the personal and cognitive deficits that result from the constant inability to predict an abuser's behavior. The battered person becomes unable to solve problems due to the overwhelming stress, and the result is often seemingly erratic and inexplicable behavior, such as returning to the batterer even following intervention.

76. WALKER, supra note 53, at 45-51. 
woman remains in a battering relationship and responds passively to abuse because her fear and inability to predict when the abuser will batter results in the belief that she cannot control what happens to her. ${ }^{7}$ Consequently, a battered woman will not attempt to leave even if it appears to outsiders that she could do so safely. While the Webb court did not permit expert testimony on battered woman syndrome, when such testimony is presented it often reinforces the learned-helplessness victim-model. This type of testimony usually describes the defendant's psychological characteristics, portraying her as suffering from a clinical syndrome, ${ }^{78}$ rather than exploring the series of events that serve to render her inferences as reasonable. In so doing, an expert may present the defendant as unable to perceive and evaluate the batterer, the relationship, and her options accurately.

Many commentators have criticized Walker's research on a number of grounds. ${ }^{79}$ While I do not dispute the very real psychological effects of battering that Walker's learned-helplessness theory details, like her critics, I suggest that empirical data supports the notion that battered women should also be framed as responsible agents rather than helpless victims. ${ }^{80}$ Neither Walker's findings nor later studies support the battered woman syndrome and its theory of learned helplessness as a pattern commonly produced by battering relationships. ${ }^{81}$ Instead, these later studies demonstrate that battered women are active help-seekers. For example, in a study examining the particular help-seeking behavior of women staying at a battered women's shelter in Texas, research showed that, rather than helpless victims,

[battered women] appear instead as "survivors," acting assertively and logically in response to the abuse. They contact a variety of "help sources," from friends and relatives to social services and the police, but with little result. The deficiencies

77. See id. at 47 .

78. See id. at $47-50$.

79. For an excellent discussion of such complaints, see Robert F. Schopp et al., Battered Woman Syndrome, Expert Testimony, and the Distinction Between Justification and Excuse, 1 U. ILL. L. REV. 45, 53-64 (1994); see also Coughlin, supra note 71, at 56-62, 70-87; Elizabeth $M$. Schneider, Describing and Changing: Women's Self-Defense Work and the Problem of Expert Testimony on Battering, 9 WOMEN's RTS. L. REP. 195, 207 (1986).

80. See, e.g., William A. Stacey \& Anson D. Shupe, The Family Secret 54 (1983) (describing the courage and resourcefulness of the women with whom the authors met during their study); see also Stark, supra note 8, at 1023 (contrasting Walker's learned-helplessness theory to explain "why a particular woman failed to utilize available escape mechanisms" with the author's proposed coercive control defense which discusses "the steps a woman has taken to control, minimize, or escape from the battering"). In all fairness to Walker, she devotes some attention to the survival skills of women who have been battered. See WALKER, supra note 53, at 20-21.

81. See Schopp et al, supra note 79 , at 63. 
seem, therefore, to be in the helping sources to which the women appeal and confide. ${ }^{82}$

When confronted with increased violence, then, battered women do not conform to the learned-helplessness model which posits that helpseeking decreases in such situations. On the contrary, help-seeking increases. ${ }^{83}$ Of course, this help-seeking may be mediated by available resources, a woman's commitment to the relationship, the number of children she has, and the kinds of abuse she may have experienced as a child. ${ }^{84}$ Expert testimony would help to explain the complex circumstances that influence the behavior of battered women charged with failure to protect. Using the objective standard of reasonableness denies jurors this information.

In addition to precluding expert testimony, frequently courts that use a solely objective test for reasonableness often exclude evidence of a prior pattern of abuse. Both types of evidence are crucial to excuse the defendant's decision to obey the batterer. This evidence can help clarify that a battered woman develops survival skills, and in light of these skills, it is reasonable to obey the batterer's instructions. For example, like June Webb, many battered women stay with their abusers to protect their children because in their view this seems to be the safest, most reasonable route..$^{85}$ Attempting to leave may often be the most dangerous step a battered woman and her children can take. ${ }^{86}$ Thus, just because June Webb chose an unattractive option does not make her choice involuntary: her "act may be unwilling, but it is not unwilled."87 Under the totality of June's circumstances-her available resources and the past pattern of her husband's battering-she made a fully controlled decision, one attended by reasonable inferences and intentional behavior.

Characterizing June's choice as involuntary implied that she was psychologically impaired, and thus harmed her credibility in raising a duress defense, because it undermined the accuracy of her perceptions and judgments regarding the batterer and the relationship. Surely, depicting a battered woman in this way affects a court's decision

82. EdWard W. Gondolf \& Ellen R. Fisher, Battered Women as Survivors 2 (1988); see also Barbara Davidson et al., Battered Women Who Kill: An Analysis of Prior Help-Seeking Behavior, in When Battered Women Are Charged with Crimes: A Resource Manual for Defense ATtORnEYS AND Expert WitNesses 1, 2 (Sept. 1996) (reporting from their study of battered women who killed their abusers that these women made between 3.4 and 4.6 attempts to end the violence before committing such acts). See generally LeE ANN HOFF, BATTERED WOMEN AS SURVIVORS (1990).

83. See GONDOLF \& FiSHER, supra note 82.

84. See id. at $18,27-38$.

85. In a sense, many women with children are not individual actors per se, because they often make decisons on the basis of the interests of their children. See Maboney, supra note 48, at 19.

86. See supra text accompanying notes 48-52.

87. Dressler, supra note 20 , at 1360. 
whether to grant her custody. If the court views the woman as suffering from battered womau syndrome, the judge may be inclined to think that she is incapable of taking care of her children ${ }^{88}$ Hence, it is imperative to frame the battered woman as a person who made a rational, voluntary choice under the circumstances. I shall next consider an approach to reasonableness which allows for this possibility.

II

\section{Self-Defense: The Hybrid Approach to Reasonableness}

While the objective approach to reasonableness presents problems for battered women, tempering it with some subjective elements significantly improves its utility. This Part will discuss self-defense which adopts a hybrid approach to reasonableness. With self-defense, the issue of reasonableness critically impacts the determination of whether a battered woman charged with homicide possesses a credible claim. At common law, a person who reasonably believes herself to be subject to an immiuent unlawful attack on her person can use as much force as she reasonably believes is necessary to protect herself. ${ }^{89}$

In comparison to the objective approach to reasonableness duress uses, courts assess evidence of self-defense from the standpoint of the reasonable person, knowing all the defendant knows and seeing all the defendant sees. ${ }^{90}$ By evaluating the evidence from this standpoint, the approach to reasonableuess incorporates both subjective and objective characteristics. It is subjective in that the jury is "entitled to stand as nearly as practicable in the shoes of [the] defendant, and from this point of view determine the character of the act." " The jury also considers the defendant's actions in light of all the circumstances known to the

88. Studies actually show that domestic violence survivors and their children readjust well after the batterer is removed, see LENORE E. WALKER, TERRIFYING LOVE 65 (1989), and that children are often better off with their natural parents than in the foster care system, see NATIONAL CounciL of Juv. \& Fam. CT. Judges, Resource Guidelines 12-13 (1995); see also Joseph Goldstein ET AL,, Beyond THE BEST INTERESTS OF THE CHILD 53 (2d ed. 1979) (arguing to replace the best-interestof-the-child standard with "the least detrimental available alternative for safeguarding the child's growth and development").

89. See DRESSLER, supra note $27, \$ 18.02$.

90. See State v. Allery, 682 P.2d 312,314-15 (Wash. 1984). As asserted in State v. Wanrow, [jurors are to] put themselves in the place of the appellant, get the point of view which [s] he had at the time of the tragedy, and view the conduct of the [deceased] with all its pertinent sidelights as the appellant was warranted in viewing it. In no other way could the jury safely say what a reasonably prudent [person] similarly situated would have done.

559 P.2d 548, 556 (Wash. 1977) (quoting State v. Tribett, 132 P. 875, 877 (Wash. 1913) overruled on other grounds by State v. Penn, 568 P.2d 797, 798 (Wash. 1977)). The trial court must evaluate the evidence from this same point of view if it is to determine properly whether the defendant has produced some evidence of self-defense.

91. Wanrow, 559 P.2d at 556 (quoting State v. Ellis, 70 P. 963, 964 (Wash. 1902)); see also Allery, 682 P.2d at 314-15. 
defendant, even those substantially predating the act. ${ }^{92}$ This subjective aspect ensures that the jury fully understands the totality of the defendant's actions from her own perspective. Such a consideration is critical in battered women's cases because the jury must inquire whether the defendant acted reasonably, given her past experiences of abuse.

The self-defense evaluation is also objective. Using the same information, jurors determine "what a reasonably prudent [person] similarly situated would have done." ${ }^{33}$ The objective portion of the inquiry serves the function of providing an external standard. Without the objective portion, a jury would be forced to evaluate the defendant's ac-tions in the vacuum of the defendant's own subjective perceptions, and self-defense would lose all of its normative components. In essence, without the objective component, self-defense would always justify homicide so long as the defendant was true to her own internal beliefs. All actions would be reasonable, because the subjective inquiry would merely ask whether this particular defendant, in her situation, would have thought it was reasonable to commit the act in question. Undoubtedly, the response would always be "of course," because the defendant did commit the act. If this were the case, the acts of those who see threats of harm where the rest of us would not, or who blind themselves to escape that seems plainly available, would be justified. Although such a person may not be as blameworthy as one who kills without any provocation, surely the law should not justify her criminal actions.

When a woman kills her batterer and pleads self-defense, courts almost unanimously agree that the defendant may present expert testimony regarding a battered woman's experiences to explain how her particular experiences as a battered woman affected her perceptions of danger and her honest belief in its imminence. ${ }^{94}$ Attorneys also offer such testimony to rehabilitate the defendant's credibility when the prosecutor has attempted to impeach her by urging that her conduct is inconsistent with her claim of self-defense. ${ }^{95}$ Unlike when a defendant

92. See Allery, 682 P.2d at 314-15.

93. Wanrow, 559 P.2d at 556 (quoting Tribett, 132 P. at 877); see also Allery, 682 P.2d at 312.

94. See, e.g., People v. Humphrey, 921 P.2d I, 8 (Cal. 1996); see ulso Holly Maguigan, Battered Women and Self-Defense: Myths and Misconceptions in Current Reform Proposals, $140 \mathrm{U}$. PA. L REv. 379, 429-31, 464-70 (1991).

95. See Humphrey, 921 P.2d at 8 (citing People v. Day, 2 Cal. Rptr. 2d 916, 922-25 (Ct. App. 1992)). Battered-woman-syndrome evidence has been admissible to support a claim of self-defense since at least 1979. See lbn-Tamas v. United States, 407 A.2d 626, $631-40$ (D.C. Cir. 1979) (finding error in the trial court's exclusion of expert testimony on the basis that it would invade the province of the jury and remanding so that the trial court could consider whether the expert was sufficiently knowledgeable and whether the expert's methodology for identifying and studying battered women was generally accepted).

In at least twelve states, legislatures have enacted statutes mandating the admission of evidence of past abuse suffered by a battered defendant who claims self-defense to explain how this abuse may affect conditions such as her perception of the danger posed by the batterer, as well as the 
invokes a duress defense, none of these courts analyze this evidence in a subjective versus objective fashion to decide on its admissibility. Rather, the courts apply a hybrid test of reasonableness. Many of these courts consider the evidence to be offered for the purpose of expanding jurors' general knowledge and understanding of precisely what the defendant's circumstances were at the time of the offense. ${ }^{96}$

\section{III \\ Comparing DuREsS and SELF-DEFenSE APPROACHES to REASONABLENESS: SHOULd THE AsYMMETRY Be SuSTAINED?}

Thus far we have examined two approaches to reasonableness that the criminal law currently adopts: an objective approach for duress and a hybrid approach for self-defense. It has been my contention that the asymmetrical treatment of reasonableness in these defenses leads to strikingly different results. A defendant who raises a claim of selfdefense stands a better chance of exoneration than a defendant who raises one of duress because duress' objective approach to reasonableness excludes evidence that is crucial to demonstrate the reasonableness of a defendant's choices. ${ }^{97}$ In comparison, self-defense's hybrid approach to reasonableness ensures that the jury fully understands the totality of the defendant's actions from her own perspective before the jury determines how a reasonable person would have behaved in those same circumstances. In this Part, I attempt to uncover the reasoning that drives this asymmetry.

As we have seen, duress and self-defense share many common elements. Like duress, self-defense requires a defendant to demonstrate that she acted reasonably in response to a reasonable fear of death or bodily injury. ${ }^{98}$ Accordingly, when a person pleads either defense, fear is her "dominant psychological state." These defenses also involve a choice of harms. The defendant who pleads self-defense must choose to injure her assailant or to yield to his aggression while the defendant who pleads duress must choose to perform what her threatener commands or

reasonableness of her response in reaction to the perceived danger. See NATIONAL Clearinghouse FOR THE DefENSE of Battered WoMen, Legislative Update 2 (Feb. 1997).

96. See, e.g., Maura Dolan, Court Ruling Aids Women Who Kill Batterers, L.A. Tmes, Aug. 30, 1996, at Al (discussing California Supreme Court's recent ruling allowing juries to consider expert testimony in deciding "whether a 'reasonable person' in the defendant's position would have felt such danger").

97. I am not suggesting that it is an easy task for a battered woman who kills her abuser to mount a self-defense case.

98. See, e.g., Stanley M. H. Yeo, Compulsion in the Criminal Law 25 (1990). Most jurisdictions hold that a person who uses deadly force in self-defense is justified only if this force is in response to an imminent threat of death or serious bodily harm, and the actor reasonably believes that the force is necessary. See LAFAvE \& ScoTt, supra note $25, \S 5.3$.

99. YEO, supra note 98. 
to "have the threat carried out."100 In either case, then, the threat the defendant meets constrains her ability to choose between the two harms; she admits to "having consciously chosen to perform the act charged but denies that it is a crime because the act was done under the influence of the threat."

Because the elements of duress and self-defense are similar, a number of scholars argue that courts should allow evidence of past abuse in cases of duress as well..$^{102}$ In People v. Romero, ${ }^{103}$ a California appellate court charted new territory when it extended the self-defense rule permitting evidence of past abuse to duress cases. ${ }^{104}$ After juxtaposing selfdefense and duress, the court found that in both cases "the evidence is relevant to the woman's credibility and to support her testimony that she entertained a good-faith objectively reasonable and honest belief that her act was necessary to prevent an imminent threat of greater harm." 105 The court found that the defendant's act must have been motivated by an actual or honest belief in imminent danger (subjective), and that a reasonable person in the same circumstances would have had the same perception (objective). Although Romero suggests that California's tests for duress and self-defense have both an objective and subjective component, the court's reasoning is just as applicable to the criminal law of other states in which their tests for duress remains objective. Romero's reasoning should equally apply to federal criminal law, where the essential elements of duress and self-defense are identical.

In a similar vein, the issue of whether the test of duress is solely subjective, or if objective, how it should be formulated, came before the

\section{Id.}

101. Id.

102. See Susan D. Appel, Beyond Self-Defense: The Use of Battered Woman Syndrome in Duress Defenses, 1994 U. ILL. L. REv. 955, 970-80; Meredith Blake, Coerced into Crime: The Application of Battered Woman Syndrome to the Defense of Duress, 9 WIS. WoMEN's L.J. 67, 84-93 (1994); Beth I.Z. Boland, Battered Women Who Act Under Duress, 28 New ENG. L. Rev. 603, 607 (1994); Doré, supra note 68, at 738; Monique M. Gousie, Comment, From Self-Defense to Coercion: McMaugh v. State Use of Battered Woman's Syndrome to Defend Wife's Involvement in Third-Party Murder, 28 New ENG. L. Rev. 453, 479 (1993).

103. 13 Cal. Rptr. 2d 332 (Ct. App. 1992) (depublished) (finding counsel acted ineffectively by failing to raise battered-woman-syndrome evidence to support a defense of duress), rev'd on other grounds, 883 P.2d 388 (1994).

104. For two courts which recently followed suit, see United States v. Marenghi, 893 F. Supp. 85, 91-97 (D. Me. 1995); State v. Krage, No. K3-91-155, at 2 (order), 1 (mem.) (Minn. Dist. Ct. 1991); see also State v. Loven, 1996 WL 280764, at *3 (Wash. Ct. App. May 28, 1996). Although the Loven court did not find for the defendant, it asserted that "[u]nder the proper facts ... [f]or example, where there is an ongoing history of physical abuse and learned helplessness, a threat to inflict injury may inform the question of whether a defendant's apprehension of immediate harm is subjectively reasonable, regardless of her opportunity to escape or seek help before committing the crime." Id.

105. Rontero, 13 Cal. Rptr. 2d at 338-39 (emphasis added). 
British Court of Appeal in Regina v. Graham ${ }^{106}$ as a matter of first impression. ${ }^{1177}$ Following the Law Commission's proposals, the court held:

It may be said that the whole test as to whether the requirements of duress exist should be subjective, but ... this would create too wide a defence. Serious personal injury can cover a wide range of threatened harm, and if the defence is to be available even in respect of the most serious offences, it would be unsatisfactory in the final event to dispense with some objective assessment of whether the defendant could reasonably have been expected to resist the threat. ${ }^{108}$

Hence, as a matter of public policy, the court adopted a hybrid test, limiting duress through an objective criterion based in terms of reasonableness. ${ }^{109}$ The court analogized duress to the defenses of provocation, selfdefense, and mistake, which each use hybrid tests. In so doing, the court noted the desirability of maintaining a consistent approach to criminal liability defenses. ${ }^{110}$

Most courts and commentators, however, hesitate to accept a hybrid test for reasonableness in the duress context. They fear that claims of subjective vulnerability pose "danger"111 and hence are "unwise" because they will open the proverbial floodgates to a stream of defendants. From the duress defense's inception, courts have been careful to curb its expansion, limiting the defense in various ways. ${ }^{113}$ Although theoretically it makes sense for both duress and self-defense to enjoy equal applicability, in practical terms, it can be argued that duress differs from self-defense with regard to (a) justification and excuse,

106. 1 W.L.R. 294 (C.A. 1982) (per curiam).

107. See id. at 298.

108. Id. at 299-300 (quoting Law Commission, No. 83, Criminal Law: Report on Defences of General Application, II 2.28 (1977).

109. See Graham, 1 WL.R. at 300.

110. See id.

111. State v. Riker, 869 P.2d 43, 51 n. 5 (Wash. 1994) (en banc). The court stated that "as a matter of public policy, the [duress] defense should be limited." Id. at 51. Otherwise, "there is a danger that the evidentiary doors will be thrown open to every conceivable emotional trauma." Id. at 51 n.5; cf. People v. Lovercamp, 118 Cal. Rptr. 110, 112 (Ct. App. 1974) (explaining that the doctrine of necessity to "excuseth the felony" poses risks because "[i]t takes little imagination to conjure stories which could be used to indicate that to the subjective belief of the prisoner conditions in prison are such that escape becomes a necessity").

In United States v. Johnson, 956 F.2d 894 (9th Cir. 1992), the Ninth Circuit urged that courts should be wary of permitting expansion of the duress defense too far and should only permit expansion if linked to "gross and identifiable classes of circumstances." Id. at 900 (citation omitted). The court found, however, that "[b]attered women are in circumstances forming such a class." Id.

112. United States v. Willis, 38 F.3d 170, 177 (5th Cir. 1994), cert. denied, I15 S. Ct. 2585 (1995).

113. See supra note 21; see, e.g., Bain v. State, 7 S. 408, 409 (Miss. 1890) ("The social system would be subverted, and there would be no protection for persons or property, if the fear of man, needlessly and cravenly entertained, should be held to justify or excuse breaches of the criminal law of the state...."). 
(b) proportionality, and (c) two- vs. three-party cases. The desire to regulate the availability of duress as a defense by the use of objective standards ostensibly relates to these differences. As the following Sections will show, however, these differences fail to provide a sufficient reason to sustain the asymmetry in the tests for reasonableness.

\section{A. Justification v. Excuse}

The separate rationales of justification and excuse themselves may explain the law's skepticism toward duress and the consequentially different treatment of reasonableness in self-defense and duress. To review briefly, Anglo-American criminal law regards self-defense as a justification and duress as an excuse. Justifications claim that the act was good, or at least legally permissible, and therefore the actor merits praise or favor rather than blame and punishment. Social utility governs whether society finds the accused's act justifiable. If her act causes less harm than the harm which she thereby avoids (she favors the superior interest), her act is justifiable. By contrast, excuses concede that the act was wrongful usually because the harm caused by the act exceeds that which it avoids. Still, excuses claim the actor should not be blamed because the threatened danger tests some individual characteristic of hers that makes it unjust for society to punish her.

The argument for limiting duress may simply be that although a claim of justification requires an actor to favor the superior interest and accordingly for society to endorse her behavior, a claim of excuse holds when society merely tolerates an actor's behavior. Moreover, claims of excuse may hold even if the costs of the defendant's acts greatly exceed the benefits. Consider the following case. A threatens to rob $B$ if $B$ does not shoot $C$ in the arm. Here, the harm to be avoided would not exceed the harm caused-B's yielding to A's threat would not produce a net social benefit. If $B$ shoots $C$, surely she would not have a justification. Perhaps, she would have an excuse of duress for her act. While we would have preferred that $B$ did not succumb to A's threat, if we assume that $B$ is not blameworthy for her actions (due to some excusing circumstances), B deserves an excuse. Because society merely tolerates rather than approves of B's behavior, most of us would probably want to ensure that B's duress defense is strictly confined according to both the time and the pressures that might influence her. ${ }^{114}$ This circumscription requires a rigorous, purely objective test.

But resting the distinction between the two approaches to reasonableness on society's level of approbation for an actor's behavior

114. See, e.g., FLETCHER, supra note $24, \S 10.3 .1$, at 801 (asserting that the theory of excuses could potentially "absorb the entire criminal law ... [raising the chance of] abandon[ing] the whole process of blame and punishment"). 
neglects an important consideration. Duress is unique among excuses in requiring a purely objective test for reasonableness. ${ }^{115}$ The reasonableness inquiries of other excuses contain both objective and subjective elements, ${ }^{116}$ and some, such as insanity and involuntary intoxication, may be completely subjective. ${ }^{117}$ If excuses, like justifications, can have subjective elements as part of their inquiries, then the argument that society's mere toleration of excuses necessitates a purely objective approach to reasonableness cannot be correct.

There may be, however, a way to refine the previous argument by narrowing its scope. One might say that duress occupies a unique status among excuses and thus it requires an objective test. Paul Robinson argues that the special circumstances under which a duress defendant acted may be difficult to measure, because "a state of coercion carries no assurances." 118 Hence, even if it were possible to replicate the circumstances under which a duress defendant acted, the extreme pressure of that particular moment could not be recreated.

In contrast, Robinson contends that excuses such as insanity, infancy, and involuntary intoxication may have objective and subjective elements as part of their inquiries, because the subjective ability or inability of an actor to conform with the criminal law's norms-what these excuses depend on-can be measured. The criminal law has developed tests to ensure that such an ability or inability meets an objective standard. ${ }^{119}$ Unlike duress, which lacks any such guarantee, these tests "automatically ensure that an excuse will be available only for defendants with a demonstrable defect that distinguishes them from the general population." 120

Admittedly, duress differs from other excuses, but a person's choice to obey or disobey a coercer depends on her subjective situation. Using a purely objective standard to determine a defendant's reasonableness is at odds with the underlying nature of excuses. In fact, if duress, as some argue, represents a concession to "human frailty,"121 and some people are more frail than others, it seems that the standard of

115. Sanford Kadish argues that in applying the objective standard, the law individualizes to some extent. See Kadish, supra note 24, at 275 . It should be noted that the law to which he refers is the Model Penal Code's formulation of duress.

116. "Subjective mental factors are obviously central to excuses ..." 2 RoBinson, supra note $24, \S 161(d)$.

117. See, e.g., Kadish, supra note 24, at 278-281 \& n.6; Interview with Sanford Kadish, Morrison Professor of Law, University of California, Berkeley, in Berkeley, Cal. (May 7, 1997).

118. 2 ROBINSON, supra note $24, \$ 177$ (c)(3).

119. Those who believe that these excuses are completely subjective would dispute this claim. A survey of courts' and commentators' opinions about whether these excuses are objective, subjective, or a hybrid is beyond the scope of this Comment.

120. 2 RoBiNson, supra note $24, \S 177(\mathrm{c})(3)$.

121. YEO, supra note 98, at 6 . 
reasonableness should vary accordingly. In fact, one might argue that the best way to achieve this individualized aim would be to use a strictly subjective approach which focuses only on the individual characteristics of individual defendants. ${ }^{122}$ Under this type of approach, we would consider what the accused reasonably believed rather than what a reasonable person in the accused's position might have believed. The British Law Reform Commission recommended just such a standard, proposing that "[a] person does an act under duress by threats if-he does it because he knows or honestly believes ... that there is no other way of preventing the threat being carried out."123 Here, the accused's actions are to be viewed from the standpoint of a person whose mental and physical characteristics are like the accused's and who sees what the accused sees and knows what the accused knows. Thus, if the accused is a timid, diminutive person, the fact-finder must consider these characteristics in assessing the reasonableness of her belief. But if the accused is a strong, brave and capable person, the fact-finder must weigh these characteristics in judging the reasonableness of her belief.

By emphasizing the actor herself, this test undoubtedly accords with the nature of excuse. Although I am not suggesting that a test for reasonableness should be that extreme, this individualistic aspect of excuse shows that the objective/subjective distinction does not correlate with the differences between justifications and excuses. As I will explain in the next Section, a hybrid test takes into account individual circumstances through its subjective prong, while its objective prong guards against the lack of automatic assurances regarding an actor's state of coercion.

\section{B. Proportionality of Force}

Alternatively, perhaps a proportionality rationale with an explicit balancing approach explains the asymmetry because crimes of selfdefense involve a proportionality-of-force concept, whereas crimes of

122. See, e.g., K.J.M. Smith, Note, Duress: The Role of the Reasonably Steadfast Man, 98 L. Q. REv. 347, 349-51 (1982) (arguing that the proper question is not what a person of reasonable firmness would do, but what it would be reasonable to expect this person, given all of her characteristics, to do).

Fletcher discusses the paradox of the common law tradition which purports to be based on a case-by-case analysis but is systematically averse to considering the "peculiarities of partieular defendants. [Courts] are committed to deciding the ultimate issue of guilt or innocence according to rules that suppress the differences among persons and situations." Fletcher, supra note 34, at 1300. In comparison, Fletcher lauds the German law's cultivation of a system of individualized excusing conditions which inquires in evcry case "whether the defcndant, as a concrete individual, can be fairly blamed for having violated the law." Id. at 1301.

123. Law Commission, No. 177, a Criminal Code for England and Wales, I 42(3)(a)(iii) (1989). The Victorian Law Reform Commission has suggested a similar subjective test for duress. See YEO, supra note 98, at 231. 
duress do not necessarily involve the same amount of force. With crimes of self-defense, a person is not justified in using excessive force in relation to the danger threatened. ${ }^{124}$ This proportionality requirement assures that the accused's response will be justified only when the resulting harm was less than ( $A$ uses deadly force against $B, B$ pinches A), or at most equal to (A uses deadly force against B, B uses deadly force to repel $A$ ), the harm that the threatened danger would have caused. Hence if A chides B, B may not use deadly force to repel A's nondeadly attack, even if deadly force is necessary to prevent A's threat. Such an approach exemplifies how justifications focus on the social utility of a defendant's acts.

With crimes of duress, "the issue is not the desirability of a particular act, but rather the blameworthiness of the actor's emotional state, character, or level of self-control." 125 Thus, even if the accused causes disproportionate harm in relation to that threatened, the law may exculpate her because no necessary connection exists between the type of crime the coercer demands and the severity of threats he makes against the accused. The harm the coercer threatens may be identical to the harm he commands (A threatens to cut off B's foot unless B cuts off $C$ 's foot), or an altogether different and sometimes disproportionate type of activity may be used against a third party (A threatens to kill $B$ unless $B$ rapes $C$, or $A$ threatens to kill $C$ unless $B$ rapes $C$ ). At a policy level, courts and commentators are concerned that if the accused avoids conviction for causing a disproportionate harm, other citizens may be discouraged from making efforts to resist coercive threats. Citizens may also begin to set their own standards for what constitutes a permissible use of force. For these reasons, it is often thought that the scope of duress should be narrowed by using an objective test of reasonableness.

This argument, though, fails to distinguish adequately between selfdefense and duress for a number of reasons. Because of the longstanding desire to limit duress, restrictions intended to safeguard against abuses of proportionality are already in place. At common law, duress was not available as a defense to murder or other particularly grievous offenses such as intentional homicide or voluntary manslaughter. ${ }^{126}$ In many states, duress continues to be unavailable as a defense to murder. ${ }^{127}$ Further, "the right to save oneself at a third person's expense must be limited more strictly than the right to protect oneself against an

124. See 2 RoBinson, supra note $24, \$ 131(\mathrm{~d})$.

125. Joshua Dressler, Rethinking Heat of Passion: A Defense in Search of a Rationale, $73 \mathrm{~J}$. Crim. L. \& Criminology 421, 446-47 (1982).

126. See Blackstone, supra note 19. Blackstone argued that a person under duress should choose "rather to die himself, than escape by the murder of an innocent." Id.; see, e.g., State v. Nargashian, 58 A. 953, 954-55 (R.I. 1904).

127. See Dressler, supra note 20 , at 1346; 2 RoBINson, supra note $24, \S 177(\mathrm{~g})(1)$. 
aggressor." ${ }^{228}$ Still another restriction on the duress defense is that the defendant or others must be threatened with significant harm: death or great bodily injury. The rationale behind such exclusions lies in the desire not to excuse greater harms, and the belief that the seriousness of the actor's offense should be directly proportional to the threat.

Moreover, because the widely-accepted approach to self-defense remains largely subjective, it focuses on a defendant's state of mind rather than on external factors such as proportionality. Although the proportionality requirement may have been more strictly enforced in the past, it is not currently. Yet self-defense still uses a hybrid test for reasonableness rather than a purely subjective test. Consequently, we should reject the argument that the issue of proportionality accounts for the asymmetrical standards of reasonableness in self-defense and duress.

Even if one wanted to argne that proportionality still accounts for the different standards of reasonableness, duress, in fact, retains an objective component by adopting a hybrid approach to reasonableness. As the court in Regina v. Graham ${ }^{129}$ found, when considering how the duress test should be formulated, the objective component should be used to limit the defense in terms of proportionality. ${ }^{130}$ Further, proportionality will be a factor, "sometimes the most important one," will have to consider in determining whether the accused is blameworthy. By adding a normative gloss on the reasonableness inquiry, the objective component avoids giving a license to defendants who commit actions society determines are disproportionate to the threatened harm.

\section{Two-vs. Three-Party Cases}

Perhaps, then, the different structures of two- and three-party cases and corresponding notions about attribution of responsibility explain why the tests for reasonableness differ. Arguably, the principal difference that distinguishes self-defense from duress involves the individual toward whom the defendant directs her crime or action. In self-defense, the defendant generally uses deadly force against her aggressor in response to the fear of his deadly force being used against her. In a twoparty case between $A$ and $B$, if $A$ threatens to kill $B, B$ is under little moral obligation to resist $A ; B$ may use deadly force against $A$. This is justifiable self-defense.

128. P.R. Glazebrook, The Necessity Plea in English Criminal Law, 30 CAMBridge L.J. 87, 89 (1972) (quoting Johannes andenaes, The General Part of the Criminal Law of Norway 165 (1965)).

129. 1 W.L.R. 294 (C.A. 1982) (per curiam).

130. See supra text accompanying note 108.

131. YEO, supra note 98 , at 105 . 
In the context of duress, the defendant who claims she acted under duress usually directs her crime against an innocent third party. ${ }^{132}$ As a typical three-party case, A wrongly exerts pressure on $B$ to commit a crime against $C$. When $A$ proposes to harm $B$ unless $B$ harms $C$, it is comparatively difficult to excuse $B$ from responsibility for her act. If the law excuses $B$ for harming $C$, the onus of A's threat shifts back not to wrongdoer $A$, but to innocent $C$. I suspect that in this second hypothetical case, most people would say that morality gives $\mathrm{B}$ a stronger reason to resist $A$ than in the self-defense case. ${ }^{133}$ Hence, the law's strict objective standards for duress may reflect the societal norm that it is worse for $\mathrm{B}$ to harm an innocent $\mathrm{C}$ than to harm a guilty $\mathrm{A} .{ }^{134}$

But if we are to accept the claim that the duress defense's use of an objective inquiry for reasonableness hinges on the innocence of the party being attacked (C), what of the following two situations? First, consider that self-defense can also be invoked against innocent aggressors. By innocent aggressors, I mean insane, incompetent or mistaken aggressors. ${ }^{135}$ These aggressors pose a danger to your life because they intend to kill you, but they remain innocent because they are not responsible for their behavior. Their behavior, rather than proceeding from character, is explained by other factors completely beyond their control. Imagine that innocent aggressor $\mathrm{A}$, driving a large truck, chases $B$ around a meadow. A tries to run $B$ down because someone has just injected $A$ with a drug that makes her temporarily crazy. ${ }^{136}$ While $A$ 's aggression against $B$ is not villainous, she will kill $B$ unless $B$ blows up the truck, killing $A$ in the process. According to Anglo-American jurisprudence, B may justifiably blow up the truck. Our law has decided that the balance of interests favors $B$ because she is the party who invokes

132. Note that this differs from the typical civil case involving a duress defense. These cases usually involve two parties. For example, if $\mathrm{A}$ gets $\mathrm{B}$ to agree to do $\mathrm{X}$ by wrongly applying pressure to $B$, duress excuses $B$ from the agreement and shifts the burden back to wrongdoer $A$.

133. The Canadian Law Reform Commission concluded that,

Despite [the] common fundamental nature [of duress and self-defense],.... the [ir] distinction is based on moral differences.... In self-defence the accused seeks protection against aggression and in so doing promotes a value supported by the law. In duress, he avoids harm wrongfully threatened to him but done so at the expense of an innocent third party or by contravention of the law and therefore does not promote a value supported by the law.

Canadian law Reform Commission, Criminal law: The General Part: Liability and DeFenses, Working Paper No. 29, 90-91 (1982).

134. For such a view, see State v. Riker, 869 P.2d 43, 51 (Wash. 1994) (en banc).

135. See George P. Fletcher, Proportionality and the Psychotic Aggressor: A Vignette in Comparative Criminal Theory, 8 IsRaEL L. REv. 367, 370 (1973) ("The problem of the psychotic aggressor is whether one may, as a matter of right, kill a faultless, insane assailant, to save oneself or another from death, rape, or serious bodily harm."); see also Laurence A. Alexander, Justification and Innocent Aggressors, 33 WAYNE L. REv. 1177 (1987); Judith Jarvis Thomson, Self-Defense, 20 Phil. \& PUB. AFF. 283 (1991).

136. This is one of Thomson's examples. See Thomson, supra note 135, at 284. 
self-defense. ${ }^{137}$ The interest in favor of self-defense always outweighs an aggressor's survival interest, even if she is innocent.

Next, consider that just as the criminal law permits killing an innocent aggressor in self-defense, it also permits killing an innocent threat in self-defense. ${ }^{138}$ This is a person (let's call her A) whom a sudden wind hurls into a well. A now threatens to squash and thereby kill $B$, who sits at the bottom of this very same well. Assume that the only way B can survive is if she vaporizes $A$ with a ray gun. (And conveniently, B just happens to have such a weapon handy.) $B$ is entitled to shoot innocent threat $A$, because otherwise $A$ will squash $B$, and in so doing, $A$ will infringe upon B's right not to be killed. ${ }^{139}$ Notice that although innocent threat poses a threat to you, unlike innocent aggressor, she does not even aggress against you. She merely falls toward you. Still, if you kill her, you will be justified.

It might strike some as curious that the survival interests of the party who invokes self-defense should be assumed to trump those of the innocent aggressor or the innocent threat. Here, however, the crucial fact is precisely this trumping. ${ }^{140}$ For if the same standard of self-defense, with its hybrid approach to reasonableness, can be invoked against innocent aggressors and innocent threats, it cannot be argued that the reason for the asymmetrical treatment of reasonableness in self-defense and duress rests on the innocence of the party being attacked.

Some might argue that a crucial difference remains: even though $\mathrm{A}$ may be an innocent attacker or innocent threat, she has attacked or threatened $\mathrm{B}$. In comparison with duress cases, $\mathrm{B}$ and $\mathrm{C}$ may both be innocent but $C$ has not attacked or threatened $B$. While this may be a valid observation about the moral differences between these two examples, it seems inconsistent to argue about C's lack of culpability when B also lacks culpability. C's innocence does not operate to the exclusion of B's innocence. Sometimes individuals have conflicting rights. To

137. See MOdel PeNal CODE § 3.11(1) (1985) (permiting self-defense against excused aggression). German and Soviet law arrive at the same result but on a different theory. They focus not on the aggressor's culpability, but rather on the defender's autonomy, so that self-defense against innocent aggression becomes a matter of "Right [which] need never give in to Wrong." Alexander, supra note 135 , at 1180 .

138. See Judith JaRvis Thomson, The Realm of Rights 369-70 (1990); see also Thomson, supra note 135 , at $287-89$.

139. Thomson discusses this example. See Thomson, supra note 138, at 369-70. As Thomson puts it, B is justified in killing A because A "will otherwise kill [her]." Thomson, supra note 135, at 288.

140. It may be that self-defense,

when properly invoked against an innocent aggressor is not always, if ever, a justification in that context. ... We can sympathize with and excuse a person who uses deadly force to fend off innocent aggressors, but we cannot say that it is right for hin to do so. Attack by innocent aggressors is better characterized as a case of duress that excuses homicide.... 
demonstrate, reconsider the innocent-threat case in self-defense. Although it is permissible to protect oneself (B) in self-defense at the expense of an innocent threat's life (A), "she may also, and simultaneously, protect herself at the cost of your life." "And if this is so, there seems to be no valid reason for arguing that $\mathrm{C}$ is more or less innocent than $B$ in the duress case.

Admittedly, $\mathrm{C}$ not being the attacker may remain the most objectionable issue to some. For those who remain unconvinced, if this is the only difference that separates self-defense and duress, then the distinction shonld not be determinative as it fails to focus on the defendant's innocence and her choice-making opportunities. In so doing, it treats duress as a justification rather than as an excuse. Unlike the defendant who raises self-defense to justify her actions, the defendant who raises dnress merely seeks to excuse her actions. When deciding whether to excuse such an agent, we must consider that she acted while under intense fear and pressnre. At that time, she chose to commit a criminal act because to her it represented the best of two very bad choices. And if placed in the same situation, the person of ordinary firmness would have chosen to do the same thing. The fact that an innocent life might be lost, while obviously a strong consideration, will not rid the agent acting under duress of the choice that she must make and the circumstances under which she must make that choice. And if the distinction is not determinative, it seems indefensible for the law to retain two different tests for reasonableness.

In the end, none of the differences that separate duress from selfdefense adeqnately explains why the criminal law uses asymmetrical approaches to reasonableness in these two defenses. Distinguishing generally between duress and self-defense based on the rationales of excuse and justification fails to supply the answer because some excuses resemble justifications in their use of hybrid, if not completely subjective, approaches to reasonableness. And distinguishing more specifically between duress and self-defense based on proportionality requirements and the structures of two- vs. three-party cases also fails to supply the answer. In terms of proportionality, although self-defense explicitly requires that a defendant's use of force be proportional to that threatened while duress does not, many jurisdictions no longer strictly enforce this requirement for self-defense. Further, if the reason for the asymmetry between the two approaches to reasonableness truly hinged on proportionality concerns, duress contains safeguards that could assuage such fears. And finally, distinguishing duress and self-defense based on the innocence of the party against whom the defendant directs her crime

141. Claire O. Finkelstein, On the Obligation of the State to Extend a Right of Self-Defense to its Citizens, 10 n. 12 (April 16, 1997) (unpublished manuscript, on file with the author). 
fails to supply the answer because just as an actor may use force against an innocent third party when she acts under duress, so too can an actor kill an innocent attacker or bystander in self-defense. Accordingly, we should reject the criminal law's asymmetrical treatment of reasonableness as between duress and self-defense by modifying duress with a hybrid approach to reasonableness.

\section{IV}

Modifying DURESS: Adopting A Hybrid APPROACH TO REASONABLENESS

The previous Parts have made two major claims. First, I have argued that duress should excuse a battered woman's reasonable survival behavior in the coercive failure-to-protect context. The application of duress to this situation implements both the traditional and modern purpose of the duress defense by providing the defendant threatened with death or great bodily harm an alternative-the commission of a criminal act or the omission of a required act. Unmodified, however, duress' objective approach to reasonableness often precludes finding that battered women who fail to protect were faced with a duress situation: it assumes no threat of imminent death or great bodily harm, no reasonable opportunity to escape, and that being battered and being reasonable are mutually exclusive. Second, I have argued that no valid reason exists to sustain this objective approach to reasonableness, and thus we should adopt a hybrid approach to reasonableness which resembles that used in the area of self-defense. By adopting the hybrid approach, duress could be broadened to encompass valid duress claims that the criminal law currently bars. This Part discusses how this modification would proceed and addresses potential criticisms it may meet.

\section{A. Proposed Standard of Duress}

I propose the following standard of duress:

The defense of duress is determined by considering whether, under the totality of the circumstances (including past abuse), the threat (implicit or explicit), or the use of force, was such that the actor believed she could not resist, and a reasonable person similarly situated could not resist.

The core elements of this proposed standard are identical to those of traditional duress: reasonableness and coercion. Under this standard, defendants could argue that they had no genuine choice about whether to commit the criminal act because (1) their act was coerced and (2) no reasonable person could have genuinely resisted the coercion (their capitulation to the coercion was reasonable). Although sometimes it might have been physically possible for the actor to choose differently, if a 
reasonable person would not have, then the actor should be exonerated. By establishing that the defendant had a reasonable perception of danger, given her experience of prior battering, duress could excuse a battered woman whose fear of her batterer led to her reasonable choice of obeying him to protect her children from a worse harm that he threatened.

\section{B. Elements of Proposed Standard}

\section{Reasonableness: Limiting the Behavior That Will Be Excused}

The most prominent change in the proposed modification is the attempt to strike a middle ground between the two polar positions of a purely objective versus a purely subjective approach to reasonableness. ${ }^{142}$ Each pole of the reasonableness inquiry protects a different value. The subjective pole fosters individualized justice and comports with our notions of culpability and human weaknesses, while the objective pole sets a "precondition to society rendering the accused blameless for the wrongful conduct." 143 The most just inquiry occupies a position about midway along this continuum: whether a reasonable person would have acted similarly in the defendant's shoes given the totality of the defendant's circumstances. This analysis resembles that used in the area of self-defense. It would individualize duress to a given situation, yet still retain the defense's normative component. Thus, a decisionmaker would ask what a reasonable person, given the defendant's experience of prior battering, would have done in the exact same situation. The standard would remain objective but be flexible enough to take into account the totality of the defendant's circumstances. It would allow a defendant to present evidence of past abuse because, by definition, its reasonable person standard, like that of self-defense, would combine objective and subjective elements. This standard would promote fairness by requiring the decisionmaker to consider the coercive effects of the defendant's circumstances.

Critics of such a modified duress defense might argue that the new defense would place us on a "slippery slope, inevitably leading to the recognition of a universal excuse based on the influence of external circumstances on an accused's choice."144 These critics should be relieved to find that a defendant would not succeed with an expanded duress claim merely by asserting that her behavior was reasonable because she

142. Elizabeth Schneider describes these positions as "poles on a continuum," because the jury must find that the defendant behaved reasonably under either. Schneider, supra note 79, at 219.

143. YEO, supra note 98 , at 232.

144. Armour, supra note 38 at 535 (describing the possible contention of such a critic); see also People v. Humphrey, 921 P.2d 1, 13 (Cal. 1996) (Brown, J., concurring) (describing the courts as "poised precariously upon the slippery slope of personalized defenses"). 
was battered. Rather, where a battered defendant raises a duress defense, the crucial inquiry regarding her culpability should be whether she has acted under a sufficient fear of harm, and whether that fear was reasonable given the totality of the circumstances. Fear of death or serious bodily injury at the hands of the abuser must be the cause of her failure to act.

For a defendant to use the defense, she must have believed that failure to comply with the coercer would result in additional injury to the child, to another person, or to herself. The standard would thus provide an excuse when the actor believes certain conditions exist. This view adopts two distinct rules: (1) the actor will get the excuse even if she is mistaken about the existence of the conditions; and (2) the actor will not get the excuse, even though the required conditions exist, if she is unaware that they exist.

Extending duress accordingly requires limiting the availability of the excuse to avoid the potential for abuse by a defendant who chooses any course of conduct to avoid the coercer's threat; this addresses the concerns about proportionality discussed earlier. For example, if A threatens B, B's action must be the least harmful of the effective options of which she is aware. If $B$ chooses what she genuinely believes is the least harmful of the effective means of avoiding A's threats, $B$ should be excused even if a less harmful option exists. This limitation would function like the requirement of necessity in justification defenses. ${ }^{145}$ Necessity demands the least harmful conduct necessary to avoid the threatened harm. The duress situation differs, however, because it is an excuse, rather than a justification. Thus, the coerced actor should be excused as long as she is "unaware of a less harmful and equally effective means of avoiding the threat."'46 The modified duress standard embodies this suggestion through its two prongs of reasonableness and coercion. If a court determines the coerced person's conduct represents the least harmful option known to her, it is reasonable.

When using this modified duress standard, the actions of a woman who has been battered should always be framed against an implicit threat of death. For a battered woman and her children, the threat of death exists continually: the batterer may fly into a violent rage at any instant. Hence, just because the batterer does not explicitly threaten to kill his mate or her children if she attempts to interfere with his abuse of

145. Some authorities continue to interpret duress as limited to conduct that the coercer demands. But, if as Paul Robinson points out, a persuasive rationale exists to excuse an agent "who acts under apprehension of impending harm ... then logically it would seem to apply regardless of the source of the threat." 2 RoBinson, supra note $24, \$ 177(\mathrm{e})(1)$. Indeed, as stated earlier, rather than distinguishing necessity and duress by the source of the threatened harm, the defenses are now more commonly distinguished by justification and excuse. See supra note 33.

I46. 2 RoBINSON, supra note $24, \S$ I77(e)(5). 
the children, it is an implicit understanding between them that his violence may escalate at any moment. ${ }^{147}$ Keeping this reality in mind clarifies issues of proportionality as between the harm threatened to the defendant and that threatened and ultimately committed against her child by the batterer.

Of course, fear alone is not sufficient, because it does not guarantee that the balance of the prospective cost to the defendant's child is minimal. The Nebraska Supreme Court, for instance, articulated the contention of a number of different courts when it stated that, "a mother's fright does not, by itself, excuse her failure to extricate children from a dangerous environment." 148 Often, it will be debatable as to whether the facts of a particular case present sufficient evidence of duress to support a jury instruction. Consider the case of Paulette Jenkins. Her husband's beating of their young daughter one night led to the child's death the next morning. ${ }^{149}$ Paulette sat in the next room with her youngest baby while the beating took place. ${ }^{150}$ Poet Anna Deavere Smith interviewed Paulette, who told her story as follows:

[T] he night that Myeshia died

I stayed in the bedroom with the baby.

And every time he would hit her

she would fall,

and she would hit her head on the tub.

I could hear it!

And it happened continuously,

repeatedly.

(She whispers.)

And I dared not to move.

I didn't move.

I didn't even go see what was happening.

I just set there and listened...

The next morning

she was dead. ${ }^{151}$

To excuse Paulette under the proposed standard, a jury would have to conclude that she was under a sufficient fear of harm, and that she genuinely believed that acting to stop the abuse or endangerment of her child would have resulted in either death or substantial bodily harm to herself or to the child.

147. See infra Part IV.B.2.a.

148. In re C.P., 455 N.W.2d 138, 145 (Neb. 1990).

149. See Anna Deavere Smith, Annals of Crime, Broken Sentences: Women in Prison Tell Their Stories Straight, NEw YoRKER, Feb. 26 \& Mar. 4, 1996, at 158.

150. See id. at 160.

151. Id. 
Although Deavere Smith does not report all of the circumstances of the case, she provides us with Paulette's description of her feelings of failure as a mother:

And he beat me too.

But

it didn't change the fact,

that

It was a nightmare for my children.

It was a nightmare.

And I failed them.

Dramatically.

Because I allowed it to continue.

On.

And on.

And on. ${ }^{152}$

Through this outpouring, Paulette reveals herself imbricated in a complex web of violence, coercion, pain, and fear. Staying in one room with her newborn might have represented one of Paulette's learned survival strategies to protect her children and herself. In the past, interfering with her husband during a violent episode may have engendered only more violence toward her children and herself. Indeed, Paulette's statement that she "dared not move" suggests such a possibility-a minute-byminute attempt to keep her loved ones alive. More information about Paulette's circumstances is needed, but if this interpretation is correct, Paulette should at least be afforded the opportunity to use the modified duress defense.

\section{Coercion: From Imminence to Totality of the Circumstances}

The other core element of the proposed standard is coercion under the totality of the circumstances. Determining whether a defendant acted under an imminent threat is part of the traditional duress doctrine's reasonableness inquiry. Consequently, the other stumbling block to raising successful duress defenses for battered women usually lies in the legislative requirement that an immediate or imminent threat of serious bodily injury exist when the defendant took action or, in failure-to-protect cases, inaction. ${ }^{153}$ The modified duress standard eliminates this obstacle by broadening the time frame. In measuring the totality of the surrounding circumstances, the jury may consider the seriousness of the danger to the defendant. Any other option would virtually guarantee

152. Id.

153. At common law, the defense of duress required "a present, immediate and impending threat of such a nature as to induce a well-founded fear of death or serious bodily injury if the criminal act is not done; the actor must have been so positioned as to have had no reasonable chance of escape." Commonwealth v. Robinson, 415 N.E.2d 805, 812 (Mass. 1981); see also Walter Harrison Hitchler, Duress as a Defense in Criminal Cases, 4 VA. L. REv. 519, 537 n.17 (1917). 
these defendants "no defense."154 To illustrate this point, imagine a jury who views the defendant's circumstances immediately prior to the commission of her crime and finds that no overt threat such as a gun to the head existed. The jury might conclude that any fear of imminent death or violence was unreasonable. However, if the court permits the defendant to pull the camera back to provide the broader picture of the totality of her circumstances, the jury could learn of a pattern of violence, control, and coercion which led up to the criminal act.

This modification does not depart radically from the rule in many jurisdictions. Some state courts have already removed the imminence limitation by holding that the trier of fact must determine the proximity of the threatened harm based on an assessment of all the circumstances. ${ }^{155}$ The Model Penal Code has also eliminated the imminence requirement, recognizing that sometimes a longer period of threats can cause more pressure than a strong imminent threat. ${ }^{156}$

Because many people believe that defendants who remain with batterers cause the long periods of threats, enlarging the duress defense to accommodate a broader time frame could be viewed as useless to the extent that these defendants would not satisfy the coercion prong. ${ }^{157}$ As

154. State v. Crigler, 598 P.2d 739, 741 (Wash. Ct. App. 1979). The Kansas Supreme Court, in considering a case involving a battered wife, explained that the "use of the word 'immediate' in the instruction on self-defense places undue emphasis on the immediate action of the deceased, and obliterates the nature of the buildup of terror and fear which had been systematically created over a long period of time." State v. Hundley, 693 P.2d 475, 479 (Kan. 1985). In State v. Wanrow, 559 P.2d 548 (Wash. 1977), the Washington Supreme Court held the instruction given by the trial court, which narrowed the focus of the inquiry to the time immediately before the shooting, was impermissible because it restricted the jury's inquiry to the surrounding circumstances. See id. at 556.

155. See, e.g., People v. Maes, 583 P.2d 942, 944 (Colo. Ct. App. 1978) (holding that fact-finder must consider all circumstances including defendant's opportunity and ability to avoid the harm); People v. Trujillo, 586 P.2d 235, 237 (Colo. Ct. App. 1978) (finding error to prohibit defendant from testifying about a series of events occurring over a period of five months); People v. Lee, 408 N.E.2d 335, 343 (IIl. App. Ct. 1980) (limiting the impact of the imminence requirement by holding that the belief in imminence need not be reasonable; the defendant can be mistaken), rev'd on other grounds, 429 N.E.2d 461 (1ll. 1981); State v. Toscano, 378 A.2d 755, 764 (N.J. 1977) (recognizing that "a per se rule based on immediate injury may exclude valid claims of duress"-those of genuine coercion based in realistic threats of future harm).

156. See Model Penal Code $\$ 2.09$ (1985).

157. Traditionally, duress did not excuse a defendant who recklessly or negligently placed herself in a situation where duress could arise. When describing the legal standard of duress today, courts often do not include this requirement. See, e.g., United States v. Bailey, 444 U.S. 394, 410 (1980); United States v. Homick, 964 F.2d 899, 905 (9th Cir. 1992); United States v. Ezeiruaku, 1995 WL 263983 at *4 (D. N.J. May 3, 1995); United States v. Bell, 855 F. Supp. 239, 241 (N.D. Ill. 1994). But see MODEl PENAL CODE $\S 2.09$ (2) (1985) (stating that duress defense is unavailable to a defendant who "recklessly" or "negligent[ly]" places herself in a situation in which it was "probable" that she would be subjected to duress). Note that under the Model Penal Code, whether a defendant was negligent in placing herself in such a situation will only be a possible ground for excluding a duress defense when negligence suffices to establish culpability. See id; see also Finkelstein, supra note 24, at 256 (stating that this requirement stands on "shak[y]" ground because of scant case law on the issue). 
noted above, this view represents an oversimplification of the complicated dynamic within which a battered woman operates. ${ }^{158}$ Partner assault involves coercion and control over every aspect of a person's life. Structural inequalities, the systemic nature of women's oppression, and the harms associated with domination and resistance reinforce this power. ${ }^{159}$ Child abuse represents an extension of the batterer's coercive tactics from mother to child. Hence, if a mother believes that her chances to escape with her children are limited, given the backdrop of the assailant's previous conduct (i.e., hunting the family down and threatening to kill them if the mother does not return to him), her escape options may be restricted. In such a situation, the word "choice" certainly takes on new meaning:

The decision to remain is strategic because it is based on an assessment of present and future harms. Although this may not be the optimal result we as a society would favor, it may be the only logical choice for the abused mother based on what she knows of the abuser. ${ }^{160}$

The coercion element of the modified duress standard would enable a defendant to explain how, in her particular case, numerous factors may have interacted to comprise her coercive circumstances.

\section{a. Allowing for Explicit or Implicit Threats}

A threat can be either explicit or implicit. Just as a defendant may believe that she or another person will be subject to death or great bodily harm if she omits or fails to commit a commanded act, the defendant may also feel the same endangerment even if the behavior is not specifically commanded. In such a situation, A does not threaten, "If you interfere, I'll shoot you and the child." Rather, such a situation might arise if, whenever $A$ beats the child, the defendant attempts to protect the child, and this action results in greater harm for both the defendant and the child. The defendant reasons from her prior experience with $A$ in similar circumstances an inference about A's likely conduct during the

158. See supra notes 43-59 and accompanying text. Furthermore, the distinction between a "normal" and violent marriage can often be illusory. When asked at forums on domestic violence why a person who has been battered might stay, social worker Donna Coker replies: "When should she have left? At what point? Maybe the time she watched while he smashed up the furniture?" Mahoney, supra note 48, at 16. After Coker poses these questions, "[a] silence, a shock of recognition, falls over the audience. It is, relatively speaking, normal for a woman to watch a man smash up the furniture. Many of the women in the room have seen something like it-and called it 'marriage,' and not 'staying.'" Id.

159. "What creates a battered woman is neither violence per se nor the psychological status of either party, but the mix of social and psychological factors that makes it seemingly impossible for the victim to permanently escape or to effectively protect herself from abuse, what we have termed "entrapment." Stark, supra note 8, at 1025.

160. Miccio, supra note 4, at 1103. 
time at issue. Based on this prior history and on whether the defendant's attempts at official intervention have been unsuccessful, A's implicit threat leads to the defendant's choice to obey him, rather than suffer worse consequences.

Indeed, a batterer need not say anything to communicate his intended threat to the person he batters. Generally, battered women can detect a change in their batterer's personality when one of his fits of violence approaches imminency. Although commentators have often framed this as a "culture of battering,"161 such dynamics are not limited to battering relationships. Understandably though, a battering relationship intensifies such sensitivities-a missed signal could mean death. Thus, it is crucial to allow implicit threats to constitute duress if a reasonable person, given the totality of her circumstances, would have also perceived the threat.

Many statutes, cases, and authorities limit the availability of duress to conduct the coercer explicitly demands of the defendant. ${ }^{162}$ But, if as I argue, the crucial inquiry regarding the actor's culpability rests on whether she has acted under a reasonable fear of harm, the coercer's explicit command to the actor to engage in the conduct constituting the offense becomes less important. Hence, a defendant charged under a child abuse statute for a crime of commission or omission that the batterer did not explicitly command could still qualify for a duress defense. The crux of excuse in general, and of this expanded defense in particular, is that the defendant was coerced. Whether the source of that coercion is implicit or explicit is not determinative. Whether the defendant's act resulted in an act of commission or omission is not determinative. The absence of genuine choice is determinative. This excuses the defendant.

\section{b. Accounting for Failures of the Legal System}

The common reason offered for the imminency restriction of duress is that proximity of the threatened harm bears a strong relation to the probability that the threat will be carried out. ${ }^{163}$ While proximity may be a significant evidentiary factor to ascertain whether the defendant is actually coerced and whether her degree of resistance is legally sufficient, adopting "an arbitrary temporal limit beyond which duress will never be recognized is to invite punishment of blameless victims of coercion." 164 This is so because:

161. Karla Fischer et al., The Culture of Battering and the Role of Mediation in Domestic Violence Cases, 46 SMU L. REv. 2117, 2117 (1993).

162. See 2 Robinson, supra note $24, \$ 177$ (e)(5).

163. See id. $\$ 177(\mathrm{e})(2)$.

164. Id. 
[i]f legal or other protection from a less than imminent harm is not accessible, and the coercer shows a clear ability and determination to effectuate his threat, the actor's exercise of free will might well be severely impaired. ... [T] hreats by one who shows that he has access to the defendant's home and family ... may well have a strong coercive effect upon a person, especially if the police are unwilling or unable to stop the threats. ${ }^{165}$

Adopting a totality-of-the-circumstances requirement, rather than one of imminence or immediacy, encourages people to turn to the legal system before taking the law into their own hands. It recognizes, however, that asking people to rely on the legal system is not always realistic. For example, although most states have statutory provisions for restraining orders to stop an abuser from contacting a victim, their effectiveness is limited for two reasons. First, abused women often cannot afford the legal fees necessary to obtain an order. ${ }^{166}$ Second, enforcement by the police and the criminal justice system is often inadequate. ${ }^{167}$

Other factors also affect a battered woman's decision whether to contact the police. For instance, few undocumented battered immigrant and refugee women seek help from the criminal justice system, the civil legal system, social services, or domestic violence programs because they fear the police or government agency may report them or their spouse, who might also be undocumented, to the Immigration and Naturalization Service. ${ }^{168}$ Mistrust and fear of law enforcement agencies and the legal system may also stem from experiencing an adverse and corrupt political environment in their home country. ${ }^{169}$ Thus, in situations where no genuine recourse to the law exists, the law should not hold defendants culpable.

The modified duress standard should be adequate to produce acquittal in those cases involving both trnly serious abuse and tangible

165. Id.

166. See Schopp et al., supra note 79 , at 84 .

167. See id. at 77-87; see also Kit Kinports \& Karla Fischer, Orders of Protection in Domestic Violence Cases: An Empirical Assessment of the Impact of the Reform Statutes, 2 TEX. J. WOMEN \& L. 163, 223-24 (1993) (reporting from their study of battered women with protcctive orders that $86.4 \%$ of the women felt that the police responded slowly or ineffectively when they reported violations of the orders, and $78.1 \%$ indicated that police response is so slow or ineffective that many do not even call to report such violations).

Joan Zorza suggests that battered women charged with failing to protect their children from the batterer should be able to raise a claim of estoppel, if they previously contacted the police about the violence, but the police failed to protect the woman and her children. Telephone Interview with Joan Zorza, former senior attorney at the National Center of Women and Family Law (October 27, 1995).

168. See Jang, supra note 54 , at 399.

169. Further, Kimberlé Crenshaw speculates that women of color in the United States often hesitate to call the police because of a general unwillingness among people of color to subject their private lives to the scrutiny and control of a police force that is frequently hostile to them. See Kimberlé Crenshaw, Mapping the Margins: Intersectionaity, Identity Politics, and Violence Against Women of Color, 43 Stan. L. REv. 1241, 1257 (1991). 
barriers to flight. Defendants would have to prove the circumstances that prevented them from seeking outside help. If a time lapse between the threat and the commission of the crime exists, the defendant will fail under this standard if a reasonable person in her circumstances would have utilized an opportunity to report the incident to the police or to run away. Arguably, defendants who unsuccessfully tried to escape in good faith have exhausted their alternatives.

Even if the defendant affirmatively failed to seek outside help, the modified duress defense would still be valid. In such a case, the defendant would have to show that she reasonably expected no intervention would have been available had she sought assistance. This expectation might be shown in a number of ways: by the defendant's consistent inability to get help from the police, by the defendant's fear of reprisals from the batterer because of previous attempts to escape which ended in greater abuse, by the fact that the defendant's community lacked any battered women's shelters that she could go to which had space for her and her children, by the defendant's inability to get help because she does not speak English, or because some shelters deny services to women who do not speak English. ${ }^{170}$

\section{Avoiding a Collapse into an Impairment Excuse}

Another objection to the proposed duress defense may be that modifying or creating defenses would encourage a proverbial army of excuse-seekers to crawl out of the woodwork, ${ }^{171}$ claiming defenses such as a "rotten social background,"172 or "Black Rage." I73 Indeed, "the fear of "bogus defences" looms large [not only] in judicial thought," but among commentators. ${ }^{174}$ The stringent requirements of the modified duress standard should address such critics who similarly argue that the standard represents nothing more than a diminished capacity or impairment defense. ${ }^{175} \mathrm{~A}$ defense of diminished capacity asserts that the

170. See Jenny Rivera, Domestic Violence Against Latinas by Latino Males: An Analysis of Race, National Origin, and Gender Differentials, 14 B.C. THIRD WORLD L.J. 231, 252-53 (1994).

171. See Alan M. Dershowitz, The Abuse Excuse: and Other Cop-outs, Sob Stories, AND EVASIONS OF RESPONSIBILITY 4, 6 (1994) (discussing the proliferation of abuse and other excuses as a "symptom of a general abdication of responsibility" that if "tak[en] ... to its logical conclusion [would result in] virtually no abusers ... ever be[ing] culpable"); CHARLES J. SyKes, A Nation of Victims: The Decay of the American Character (1992); cf. Stephen J. Morse, The "New Syndrome Excuse Syndrome," 1995 CRIM. JusT. ETHICs 3, 4 (arguing that while new syndrome evidence should be admissible to support traditional affirmative defenses, new syndromes should not be used to expand or create affirmative defenses, especially justifications).

172. See supra note 22.

173. See Peter Noel, Rage of an Invisible Man: The Trials of Colin Ferguson, Village Vorce, Feb. 21, 1995, at 21.

174. J.C. Smith, Justifiction and Excuse in the Criminal Law 97 (1989).

175. One public defender asserts that, when attorneys try to argue duress defenses for battered women, judges often accuse them of trying to equate duress with diminished capacity. Telephone 
defendant was incapable of forming the mental state required for a crime because of some mental disease, defect or intoxication, and thus she cannot be punished. While the subjective component of this expanded duress standard presents a strong temptation to transform duress into a sui generis excuse for impairment, one of the defining characteristics of duress is that it does not negate intent. The defendant's choice, no matter how unpleasant, is a rational aud willed one. Hence, no impairment exists.

Moreover, the jury system is a mechanism that would constrain a defendant's success with the defense. A defendant would have to convince the entire jury of the reasonableness of her actions and the coercion by the batterer. Our system of jurisprudence presumes that jurors represent a community's standards. Community standards should distinguish between valid excuses and ones that are the creation of attorneys. The jury system, therefore, will help protect against sliding down the slippery slope of excuse that critics fear an expanded duress claim would produce.

The modified duress standard should also satisfy those who worry that expanding the duress defense to accommodate defendants such as battered women stigmatizes women by reinforcing sexist stereotypes. In her article, Excusing Women, ${ }^{176}$ Anne Coughlin argues that, just as the marital coercion doctrine vanished in the mid-1970s, it "reemerged in the guise of battered woman syndrome defense." 177 The marital coercion doctrine presumed that a married woman who committed a crime in the presence of her husband acted under his coercion and therefore was not criminally responsible. ${ }^{178}$ While "battered woman syndrome defense" is a misnomer because no such defense exists, ${ }^{179}$ Coughlin

Interview with Kort Gatterdam, Assistant Ohio State Public Defender, one of the attorneys who represented Edna Mae Engle in State v. Engle, 660 N.E.2d 450 (Ohio 1996) (March 1, 1996). See supra note 72.

176. Coughlin, supra note 71 .

177. Id. at 29.

178. See Blackstone, supra note 19, at *28-29. At common law, duress, referred to as "duress per minas," comprised one of three forms of compulsion that courts and commentators believed deserved exoneration. The second form was marital coercion, which governed persons in "private relations ... where constraint of a superior is allowed as an excuse for criminal misconduct" and applied principally to the "matrimonial subjection of the wife to her husband $\square$." Id. at *28. Under the marital coercion doctrine, a wife was not punished for criminal conduct if she acted under the coercion of her husband. Coercion was presumed by the sheer presence of the husband at the time of the offense. See id. Even in his absence, proof of the husband's command to commit the crime was sufficient to excuse the wife. See id. Exceptions to this rule existed, including murder, treason, and crimes which were generally "presumed to be managed by the Intrigues of [the female] Sex," such as keeping a brothel. William Hawkins, A Treatise of The Pleas of the Crown 2-3 (2d ed. 1724). Necessity represents the third form of compulsion. See BLAckstonE, supra note 19, at *3031.

179. This point is often confused in the cases and commentary. See, e.g., United States v. Homick, 964 F.2d 899, 905 (9th Cir. 1992) (stating that battered woman defense is a species of 
asserts that the marital coercion doctrine denied that women possessed the capacity for rational choice. Similarly, Coughlin argues that battered-woman-syndrome defense posits that a woman's conduct was unreasonable, but then "excuses her from criminal liability if she can prove that she was a passive, obedient wife whose choices were determined not by her own exercise of will, but by the superior will of her husband." 180 Coughlin's argument also relates to the assertions of those who urge that battered women who kill their abusers in self-defense should be justified rather than excused because of the different ideological message implied when society justifies a woman's behavior as opposed merely to excusing it. ${ }^{181}$

One can easily distinguish the marital coercion doctrine from the proposed duress standard because no presumption of innocence exists with duress. Duress exists when, under the totality of the circumstances, the threat or the use of force was such that the defendant believed she genuinely could not resist and a reasonable person in the actor's circumstances genuinely could not resist. In contrast to the marital coercion doctrine and the way battered woman syndrome has traditionally characterized battered women, this model does not valorize or excuse violence that women commit. To the contrary, it stresses a responsible actor who possesses self-direction and exercises agency. In this way, it also distinguishes between mothers who hurt their children and mothers who hurt their children in an effort to protect them, even if the criminal law insists on criminalizing the mothers' behavior as a failure to protect them.

\section{V}

\section{Surmounting Other Obstacles: Making Duress} Available to Excuse All Crimes

Additional obstacles to mounting a duress defense may arise depending on the jurisdiction in which the case is tried. Failure-to-protect statutes in different jurisdictions criminalize a variety of criminal behaviors, with courts in each jurisdiction providing their own interpretations. The failure-to-protect statutes of some states include acts of

duress); Steven D. Rittenmeyer, Of Battered Wives, Self-Defense and Double Standards of Justice, 9 J. CRIM. JuST. 389, 390 (1981) (describing a "battered wife syndrome defense"). Battered woman syndrome, however, is not a defense; it may be used as evidence to support a defense such as duress or self-defense.

180. Coughlin, supra note 71 , at 50.

181. See, e.g., Phyllis L. Crocker, The Meaning of Equality for Battered Women Who Kill Men in Self-Defense, 8 Harv. Women's LJ. 121, 131 (1985) ("By focusing on the actor as wrong but pardonable, excusable self-defense would imply that her response was typically and idiosyncratically emotional. The doctrine would perpetuate the views that the woman could not have been rational in assessing the danger and that the legal system must compensate for her mental and physical weaknesses."). 
murder and strict liability crimes. Various jurisdictions and legal commentators disagree about whether duress can excuse both of these types of crimes. Like the Model Penal Code, the standard I have suggested makes duress available as a defense to all crimes. The following two Sections will argue that duress should be available as an excuse for both crimes of murder and strict liability.

\section{A. Duress as a Defense to Murder}

Sometimes, when the abuser murders a child, the battered woman's actions, or failure to act, can result in a charge of murder on theories ranging from accomplice liability and child endangerment to the failure to obtain medical aid. ${ }^{122}$ In determining whether duress should be available as a defense to murder, the distinction between justification and excuse becomes paramount. Excuse theory condemns the conduct and exculpates the actor. Hence, although murder is abhorrent, if one accepts that the reasonable person cannot be expected to withstand certain threats, then a person who kills under such threats should be excused. A killing might be unlawful, unjustified, and murderous, but nonetheless be excused under the unique circumstances of the case. Moreover, human threats cannot always be overcome or avoided. To circumvent attempted resistance, the coercer can always alter his strategy or increase the coercive force as required.

Further, many theorists urge a rights-based argument ${ }^{183}$ concerning coercion. They stress self-preservation at all costs by focusing on those instances when a defendant under duress acts to save only her own life by taking that of another. For example, Anthony Kenny writes,

[i]t is a very great misfortune to be placed in a situation where one must kill and suffer the consequences, or be killed oneself: any man must pray never to be thus placed between the devil

182. See, e.g., Boone v. State, 668 S.W.2d 17, 20 (Ark. 1984) (affirming second-degree murder conviction of mother for death of her four-year-old son based on circumstantial evidence that she exposed him to beatings by. her boyfriend); Palmer v. State, 164 A.2d 467, 474 (Md. 1960) (convicting defendant of involuntary manslaughter for criminal negligence where her boyfriend beat her child and the beatings resulted in the child's death); State v. Engle, 660 N.E.2d 450 (Ohio 1996) (indicting defendant for child endangerment); Commonwealth v. Howard, 402 A.2d 674, 678 (Pa. Super. Ct. 1979) (upholding mother's conviction of involuntary manslaughter for failure to protcct her fiveyear-old child from abuse inflicted by her boyfriend); State v. Williquette, 385 N.W.2d 145 (Wis. 1986) (convicting mother of second-degree murder for leaving her two children with her husband who abused the children).

183. For a completely rights-based view of self-defense, see Thomson, supra note 135 , at 299. 300 (contending that it is permissible to kill a person threatening you because if they kill you, they will violate your right not to be killed). But cf. Michael Otsuka, Killing the Innocent in Self-Defense, 23 PHIL. \& PUB. AFF. 74, passim (1994) (arguing that it is impermissible to kill an innocent aggressor or an innocent threat to prevent oneself from being killed). 
and the deep blue sea. But if the law takes away the deep blue sea, a man will go wherever the devil drives. ${ }^{184}$

George Fletcher states that, "[i]f [the] actor's life is at stake and he must kill an innocent man in order to survive ... he does not act to further the greater good, for the two competing lives are of the same value. Nonetheless, his instinctive effort to save his life would presumably be excused." 185 This is so because even if we believe that the actor was selfish because he was unwilling to make a personal sacrifice for the sake of another person, excuses assess the actor's responsibility under the circumstances rather than assess her act in abstraction. And while a person with extremely high standards of morality and heroism might submit to being killed rather than take the life of another person, the only relevant question is what the ordinary person would have done.

In contrast to these examples of self-preservation, when a coerced battered woman is charged with the murder of her child, she often performed her actions or inactions altruistically - they were done precisely to save the child or her other children from a worse fate. Assume that $A$ threatens to kill B's child, C, if B does not refrain from trying to stop A from merely slapping $C$. And what if the coercer threatens not only one child, but several: A threatens to kill all of B's children-C, D, E, and $\mathrm{F}$-if $\mathrm{B}$ does not refrain from trying to stop A from merely slapping $\mathrm{C}$. A obeys, but $C$ dies from A's slap. If $B$ is being charged on a theory of accomplice murder for C's death, her efforts turned out to be a miscalculation, but "[a] difficult choice among many difficult choices, even one that, in hindsight, turns out to be wrong, is not necessarily a culpable choice." 186 The person who must make such a choice should not be deprived of her right to argue duress.

\section{B. Duress as a Defense to Strict Liability}

Even though an examination of the language of failure-to-protect statutes reveals that they do not include crimes of strict liability, courts have increasingly begun to construe them in this fashion. ${ }^{187}$ One scholar

184. Anthony Kenny, Duress Per Minas as a Defence to Crime: II, 1 LAw \& PHLL. 197, 205 (1982).

185. Fletcher, supra note 34 , at 1276.

186. Richard A. Rosen, On Self-Defense, Imminence, and Women Who Kill Their Batterers, 71 N.C. L.REv. 371, 399 (1993).

187. See, e.g., In re A.D.R., 542 N.E.2d 487 (11l. App. Ct. 1989) (holding "[f]ather's repeated physical abuse of mother for seven years created injurious environment to child's welfare and could be found to constitute neglect or abuse supporting wardship determination"); In re Holmes, 328 N.E.2d 35, 36 (111. App. Ct. 1975) ("Appellant's contention that she personally committed no act of violence toward Timothy is ... totally beside the point"); In re Julie E., 451 N.W.2d 576, 582 (Mich. Ct. App. 1990) (terminating mother's parental rights because she "allowed" husband to continually create abusive environment and stating state supreme court recently clarified that "neglect" in state juvenile code is without regard to intent); In re Lynelle W. 578 N.Y.S.2d 313 (N.Y. App. Div. 1991) 
observes that courts have interpreted the minimum degree of care standard against which parental conduct is measured to include the prevention of harm, thereby mistakenly transforming minimum degree of care into strict liability. ${ }^{188}$ In so doing, a duress defense becomes difficult, because courts may contend that no defense exists to strict liability crimes.

Strict liability offenses do not require a culpable mental state with respect to the proscribed conduct or results. Thus, if Jimmy exceeds the speed limit, despite making every effort to avoid exceeding that limit, the criminal law holds him culpable. Jimmy will be held liable even though he did not intend to speed. Usually, strict liability crimes are reserved for a special class of public welfare offenses, such as selling liquor to minors or selling adulterated food, which carry a light penalty and no moral stigma. ${ }^{189}$ In failure-to-protect cases, the penalty is far from light. Of course, the degree of punishment depends upon whether

(finding mother, who did not directly participate in stepfather's sexual abuse of her daughter, guilty of child abuse for failing to protect, because evidence established that she knew or should have known about the abuse and did nothing to prevent it); In re Glenn G., 587 N.Y.S.2d 464, 470 (N.Y. Fam. Ct. 1992) (adopting strict liability as standard for neglect proceedings); In re Katherine C., 471 N.Y.S.2d 216, 218 (N.Y. Fam. Ct. 1984) ("Iglood faith, good intentions, and even best efforts, are not, per se, defenses to a child protective petition"); State v. DeBerry, 408 S.E.2d 91, 95 (W. Va. 1991) (holding state's child abuse and neglect statutes did not require a showing of either intent or civil negligence).

188. See Miccio, supra note 4, at 1096; see also Enos, supra note 4, at 229. For an excellent discussion of the dangers of this move, see Miccio's article, in which she argues that "because of the frequency and unpredictability of violence against women by intimate partners, strict liability portends a culture in which removal of children, the break-up of the family (mothers and children), and state control over mothers and children become the rule and not the exception." Miccio, supra note 4, at 1095. For such a society, see Margaret ATwood, The Handmaid's TAle (1986) (hypothesizing a future dystopia which defines women simply by their biological usefulness to soeiety and ultimately leads to their exploitation and disembodied commodification).

Construing failure-to-protect statutes as crimes of strict liability obscures violence against the mother and, in this way, fits into the biased nature of failure-to-protect statutes. See, e.g., Miccio, supra note 4 , at $1087-90$. The mother's failure is foregrounded because, "[B]y focusing on the mother's conduct, the father's assaultive conduct is viewed in the context of what the mother failed to prevent. Accountability is defined, and culpability assessed, in terms of maternal failure, as well as paternal abuse." Id. at 1095.

189. See LAFAve \& ScotT, supra note $25, \S 3.8$. Criminal liability is predicated solely on a voluntary act and need not be predicated additionally on a showing of a culpable mental state or negligence.

Many have lodged strong attacks against retaining the category of strict liability crimes, arguing not only that they are unconstitutional, but that they are also unwise. See, e.g., C. Peter Erlinder, Mens Rea, Due Process, and the Supreme Court: Toward a Constitutional Doctrine of Substantive Criminal Law, 9 AM. J. CRIM. L. 163 (1981); James J. Hippard, Sr., The Unconstitutionality of Criminal Liability Without Fault: An Argument for a Constitutional Doctrine of Mens Rea, 10 Hous. L. REv. 1039 (1973); Herbert L. Packer, Mens Rea and the Supreme Court, 1962 SuP. CT. Rev. 107, 109-110; Alan Saltzman, Strict Criminal Liability and the United States Constitution: Substantive Criminal Law Due Process, 24 WAyne L. Rev. 1571 (1978). Alternative approaches to strict liability have also been proposed. For example, the Model Penal Code limits strict liability within the code to certain minor offenses, see MODEL PENAL CODE $\$ 2.05(1)(a)$ (1985), and provides that offenses outside the code must be treated as very minor unless a mental state is proved, see id. $\$ 2.05(2)$. 
the government has charged the defendant with a misdemeanor or felony. What remains constant, however, is the likelihood that the government will take away custody of the defendant's children. ${ }^{190}$

A New Mexico case demonstrates the potential difficulties of using a duress defense when the court construes even a "knowingly, intentionally or negligently" statute as one that imposes strict liability. ${ }^{191}$ The statute at issue held that:

Abuse of a child consists of a person knowingly, intentionally or negligently, and without justifiable cause, causing or permitting a child to be:

(1) placed in a situation that may endanger the child's life or health; or

(2) tortured, cruelly confined or cruelly punished ....

Whoever commits abuse of a child is guilty of a fourth degree felony, unless the abuse results in the child's death or great bodily harm, in which case he is guilty of a second degree felony. ${ }^{192}$

Dorothy Lucero was convicted of child abuse under the above statute for allowing her live-in boyfriend, Eddie, to beat her child periodically. ${ }^{193}$ Dorothy stated that she would yell at Eddie after such an incident and testified that she was unable to contact the police or to get help for her son, because Eddie threatened to inflict more harm on her and her child if she intervened ${ }^{194}$ Eddie regularly beat Dorothy and broke her jaw on one occasion. ${ }^{195}$ She sought to defend her "inaction" by raising a duress defense. Despite the statute's language, the trial court held that it created a strict liability crime. ${ }^{196}$ The New Mexico Supreme Court affirmed, upholding the conviction and endorsing the trial court's analysis of the statute as one of strict liability, because of the "obvious public interest of prevention of cruelty to children."197

190. See Miccio, supra note 4, at 1093; Enos, supra note 4, at 229.

191. In Santillanes v. State, 849 P.2d 358 (N.M. 1993), the court interpreted the term "negligence" as contained in the statute to require criminal negligence. See id. at 366; see also Gregory P. Williams, Note, The Child Abuse Statute Now Reguires Criminal Negligence: Santillanes v. State, 24 N.M. L. REv. 477 (1994). The court, however, did not overrule Lucero, and there have been no subsequent published decisions addressing the issue. Accordingly, the status of the statute remains uncertain.

192. State v. Lucero, 647 P.2d 406, 407 (N.M. 1982) (quoting N.M. STAT. ANN. $§ 30-6-$ I(C) (Michie 1978 \& Supp. 1981)).

193. See Lucero, 647 P.2d at 406-07.

194. See id. at 407.

195. See id.

196. See id. The court held that the rationale of a strict liability statute is that the public interest in the matter "is so compelling or that the potential for harm is so great, that public interests override individual interests." Id. at 408 . In a 1975 case of the same name, the New Mexico Court of Appeals not only upheld this statute as constitutional, but declared it to be one of strict liability. See State v. Lucero, 531 P.2d 1215 (N.M. App. 1975).

197. Lucero, 647 P.2d at 408. 
Putting aside the obvious misinterpretation of the above statute as one of strict liability, under both the traditional duress standard as well as the one this Comment proposes, this interpretation does not render a duress defense obsolete. Other courts, including even the New Mexico Supreme Court, have held that crimes of strict liability do not bar the availability of an affirmative defense of duress. ${ }^{198}$

Because the Lucero court found no mens rea requirement in the child abuse statute, it determined that any evidence of duress would be irrelevant, and thus ruled it inadmissible, stating that Dorothy's intent was not material to the child abuse charge. ${ }^{199}$ In this way, the court fell into a common mistake: it viewed duress as negating the mens rea required for criminal culpability ${ }^{200}$ rather than recognizing duress as an excuse which negates the culpability factor required for the offense.

Duress does not preclude a finding of the voluntariness required for criminal responsibility, because the defendant, though motivated by an impulse to save herself or another from serious harm, still chooses to act upon that intention. ${ }^{201} \mathrm{~A}$ duress defense does not demonstrate that the defendant lacked the requisite mens rea to be found guilty of a crime. Rather, "[t]he defense assumes that the defendant has voluntarily performed the criminal act"202 and excuses the defendant who, possessing the mental state a crime requires, commits that crime, but "lack[s] general blameworthiness and [thus] should not be punished."203

If duress negatives the requisite mens rea as the Lucero court posits, the common law rule barring duress as an excuse to intentional killings would never have arisen, because the threat of harm would preclude the defendant's capacity to intend death and so constitute a defense to murder of the intent-to-kill variety. ${ }^{204}$ A's lack of capacity to intend B's death would constitute a defense to B's murder. ${ }^{205}$ But it does not. This

198. See, e.g., Lyden v. Howerton, 783 F.2d 1554, 1556 (11th Cir. 1986) (finding duress defense available to a strict liability offense of bringing Cuban refugees without visas to the United States); State v. Baca, 845 P.2d 762, $768-69$ (N.M. 1992) (finding duress defense available to a strict liability charge of felon in possession of firearm); State v. Castrillo, 819 P.2d 1324, 1328, 1329 (N.M. 1991) (same); State v. Buttrey, 651 P.2d 1075, 1079 (Or. 1982) (stating defendant might avoid conviction for conduct which is otherwise criminal by establishing one of affirmative defenses, such as duress, enumerated in strict liability statute).

199. See Lucero, 647 P.2d at 408-09.

200. See, e.g., People v. Condley, 138 Cal. Rptr. 515, 522 (1977); Rollin M. Perkins, The Doctrine of Coercion, 19 Iowa L. REv. 507, 507 n.1 (1934).

201. See, e.g., STEPHEN, supra note 21 , at 108; Williams, supra note $25, \$ 242$.

202. United States v. Johnson, 956 F.2d 894, 897 (9th Cir. 1992).

203. Martin R. Gardner, The Mens Rea Enigma: Observations on the Role of Motive in the Criminal Luw Past and Present, 1993 UTAH L. REv. 635, 738 (arguing that the evil motive concept of mens rea figures prominently at the defense level in providing doctrinal support for excuse defenses).

204. See LA FAVE \& ScotT, supra note 25, \$5.3 n.4.

205. See id. 
supports the idea that an act committed under duress is willful and voluntary.

Further, because in a criminal trial the prosecution must prove intent beyond a reasonable doubt, common sense tells us that if duress merely equalled lack of intent, as a constitutional matter, the prosecution would have to prove lack of duress beyond a reasonable doubt. ${ }^{206}$ As with the general federal practice, however, once a defendant introduces evidence sufficient to warrant a jury instruction on a duress defense, the government must disprove at least one element of that defense beyond a reasonable doubt. ${ }^{207}$

Hence, even if the New Mexico statute were a strict liability measure, the Lucero court should have considered Dorothy's claim of duress if the evidence plausibly supported it. Under the proposed duress standard, for instance, if Eddie threatened to kill Dorothy and her child if she intervened, and Dorothy, based on the totality of circumstances, found it reasonable to obey him to avoid a worse fate, she should be afforded a duress defense for her crime. The defense would be allowed not because Dorothy lacked the intent to endanger her child, but because her motives for not interceding would not be sufficiently blameworthy to hold her morally responsible. ${ }^{208}$

\section{CONCLUSION}

The purely objective approach to reasonableness that traditional duress currently dictates severely limits the ability of battered women to use this defense, particularly in the failure-to-protect context. Modifying duress to include a hybrid approach to reasonableness, as used in self-defense, and a totality-of-the-circumstances requirement more closely aligns the duress defense with its underlying excuse rationale, which posits that punishing coerced and reasonable behavior is unjust. Admittedly, the claims of all battered defendants are not valid. This expanded analysis would proceed as a general matter, recognizing that genuine instances of criminalized coercion and reasonable survivor behavior ought to be exculpated by duress. Not just a "conjured afterthought," ${ }^{209}$ the proposed duress standard retains many traditional duress limitations. As modified, the defense requires offenders to show that circumstances compelled, not merely encouraged, their conduct. Simply because a defendant claims she did not possess a genuine choice

206. See id.

207. See United States v. Mitchell, 725 F.2d 833, 836 (2d Cir. 1983); see also United States v. Campbell, 609 F.2d 922, 925 (8th Cir. 1979); United States v. Hearst, 563 F.2d 1331, 1336 n.2 (9th Cir. 1977).

208. See Gardner, supra note 203, at 739.

209. State v. Cross, 391 N.E.2d 319, 323 (1979). 
not to violate the law will not make it so. In each case, the fact-finder will fully scrutinize both the defendant's credibility and her evidence.

This proposed standard cannot eliminate the many assumptions and biases that the legal system and society as a whole embrace. These assumptions and biases may affect the ultimate success such a modified duress standard meets. However imperfectly, the modification attempts to empower and support the battered women and their children who have suffered psychologial and physical brutality at the hands of their intimate partners and fathers or father-figures. It underscores the fact that battering is a coercive circumstance that forces battered women to find innovative but apparently criminal ways to guarantee survival for themselves and their children. Such an approach emphasizes, where applicable, the extent to which a battered mother made reasonable choices, resisted coercion, and exercised agency by actively or passively taking rational measures to avoid further danger to both herself and her children. By allowing representations of women in those contexts where they are targets of coercive and violent conduct as neither wholly empowered, nor wholly incapacitated, the modified duress standard works against the polar images of women presented by the learnedhelplessness model. It assumes that women's descriptions of their experiences are "accurate, reasonable and potentially understandable given the conditions under which [they] live."210 The modification allows women to assert a duress defense when, ironically, they are charged with "failing" to protect the very children whom they are so desperately trying to keep alive.

210. See Littleton, supra note 55, at 27. In fact, battered women are the best judges of whether or not they are being battered, and they rarely exaggerate. See WALKER, supra note 53, at xiv. If a battered woman errs in her judgment, this usually involves denying or minimizing the battering. See id. 